\title{
LEAVING THE DESERT: ACTORS AND SUFFERERS IN THE ABORIGINAL EXODUS FROM THE WESTERN DESERT
}

\author{
Jeremy Long
}

In 1980 the Australian Parliament passed the Aboriginal Development Commission Act providing for the establishment of a Capital Account to promote Aboriginal 'development, self-management and self-sufficiency ... . as a recognition of the past dispossession and dispersal' of Aborigines and Torres Strait Islanders. 'Dispossession and dispersal' is an apt summary of the experience of Aboriginal people as they came progressively into contact with settlers around Australia in the years after 1788 and most notably in the fifty years between 1830 and 1880 when the pastoral frontiers were expanding rapidly. But the emergence from their desert homelands of small groups of Aboriginal people in October 1984 and again in October 1986 provided reminders that 'dispossession and dispersal' was not the experience of all Aboriginal groups in all parts of the continent. Large tracts of desert and semi-desert country in the interior, and smaller areas of relatively rugged and inaccessible forest and swampy country in, for example, the tropical coastal regions, have never been settled and there has been no dispossession, no ousting of the original inhabitants. In a few parts of these remote regions settlement was attempted only to be abandoned in the face of Aboriginal resistance and a difficult environment, but for the most part no settlement has ever been even attempted.

The Simpson Desert is one such region (Hercus 1985) and the Western Desert is another and the largest. Extending from the Nullarbor Plain in the south to the Kimberley cattle country in the north and between the limits of pastoral occupation in Western Australia on one side and in the Northern Territory and South Australia to the east and including the Great Victoria, Gibson, Great Sandy and Tanami Deserts, the Western Desert has remained for practical purposes part of 'Aboriginal Australia' rather than of 'White Australia'.1

Jeremy Long retired from the Australian Public Service in 1987 after serving as Commissioner for Community Relations (1982/86) and Deputy Secretary in the Department of Aboriginal Affairs (1975/82). He earlier worked in the Northern Territory as patrol officer (1955/57), settlement superintendent at Haasts Bluff (1958/59) and research officer $(1960168)$.

* When the late Dr Diane Barwick and others were first planning to produce this journal of Aboriginal History, I gave her an undertaking that I would offer an article on the contact history of the Pintupi. I have been able belatedly to make good this commitment mainly because the Australian Institute of Aboriginal Studies in April 1987 gave me an appointment as a visiting research fellow and made available an office and other support. I acknowledge with grateful thanks the help of my colleagues at the Institute, and in particular Mrs Pat Ware who has seen countless drafts throush the word processor, and of Mr Dick Kimber of Alice Springs who has patiently read some of those drafts and offered many comments, corrections and additional information.

1 Cf. Rowley's distinction between 'Colonial Australia' and 'Settled Australia' in The destruction of Aboriginal Society, Appendix B:375-378. The areas referred to here are shown as Aboriginal reserves or as 'thinly settled or unoccupied' in Rowley's map p.377. 
ABORIGINAL HISTORY 1989 13:1

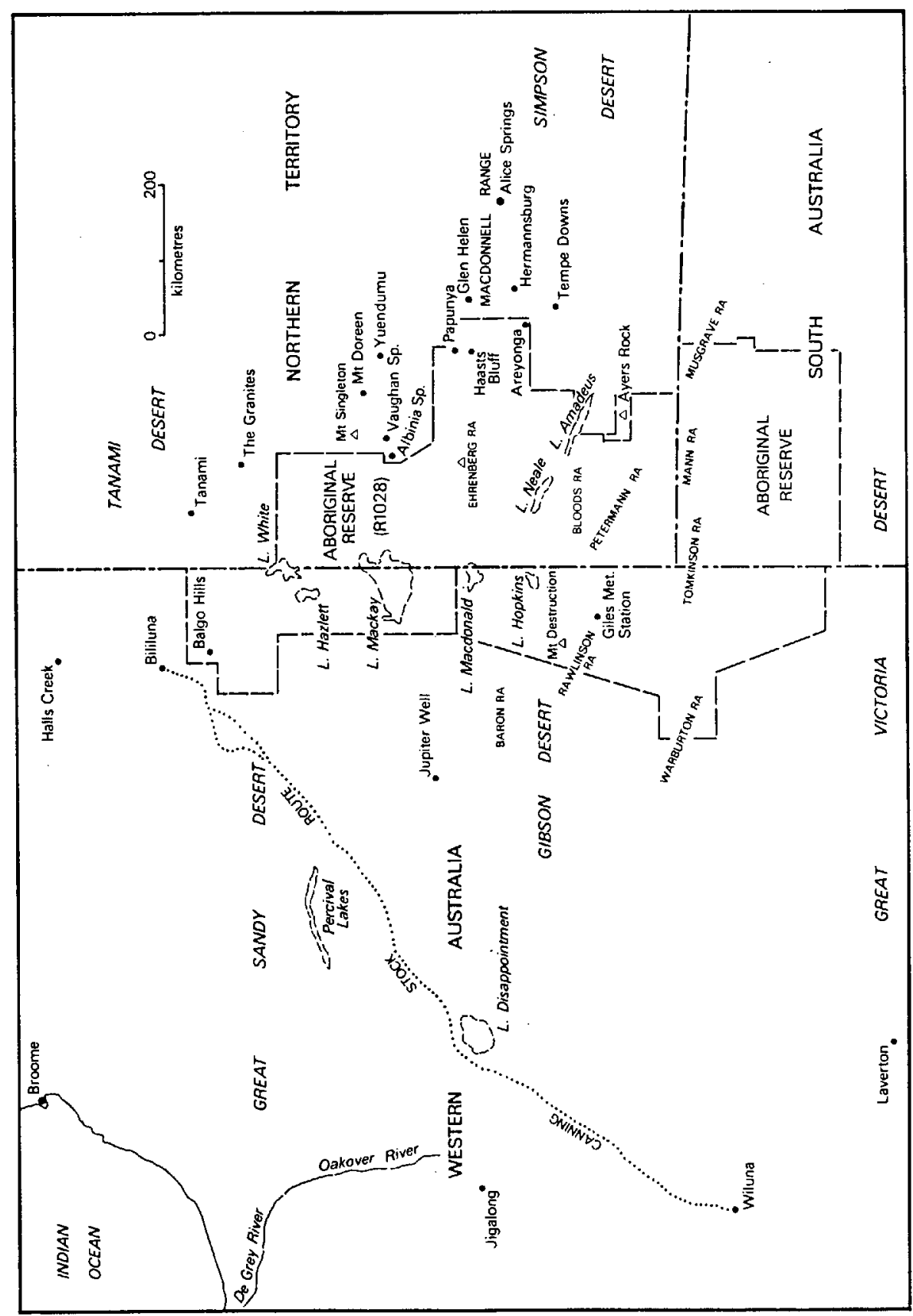

Locality map, Central Australia [John Heywood, Cartographic Unit, RSPacS] 


\section{LEAVING THE DESERT}

In the nineteenth century the inhabitants of the Western Desert lived largely unaware of and scarcely affected by the long and troubled history of settlement in Australia. Several small parties of men with camels and horses passed through the region on exploring expeditions between 1872 and 1874 and at long intervals during the next eighty years. Early in this century a fragile line of wells, marked on maps as the 'Canning Stock Route', was sunk in the west of the region and for some fifty years herds of cattle were occasionally driven from north to south along this $1200 \mathrm{~km}$ trail. The Trans-Australian Railway line was completed through the southern edge of the area in 1917. Church missions and governments established a scattering of communities on the desert fringes and in one notable instance missionaries, acting in defiance of State government policy, established themselves at the Warburton Ranges in the heart of the region in 1933.

By 1958, 170 years after the first British settlement on the continent, there probably remained about 200 Aboriginal citizens of Australia many of whom had never laid eyes on any white person and who still supported themselves in or near their traditional lands. A monarch in England had claimed sovereignty over their lands in international law but colonial, state and federal governments in Australia had done little to disturb their enjoyment of their traditional rights to occupy and use these lands. Yet most of the traditional inhabitants of this vast area, amounting to perhaps one quarter of the land surface of Australia, had already left their homelands and had moved out to live at cattle and sheep properties, mission stations, government ration depots and settlements, mining townships and railway sidings on the fringes of the desert.

Some have been inclined to take it for granted that Aboriginal people would be attracted from 'the bush' to live in association with the settlers but it does not seem immediately obvious that the attractions of the settled areas would have been strong enough to prompt long treks across unfamiliar territory to live among strangers. Some of the early emigration took place when the cattle stations on the desert fringes were by all accounts dangerous places, and places where a lot of work was demanded in exchange for meagre rations. ${ }^{2}$. Many observers have therefore found it puzzling, even upsetting, that so many Aboriginal people should have left their homelands, moved by 'some irresistible attraction towards centres of white man's culture' ${ }^{3}$ Explanations have generally emphasised the attraction 'of a regular and dependable food supply for a lesser effort than is involved in nomadic hunting and foraging 4 and for the desert people an assured supply of good water is likely to have been a significant advantage. But less tangible attractions are mentioned by some who have suggested that 'sheer curiosity' may have been more important than any hankering for material goods among the desert people 5 .

Those who have been inclined to assume that Aboriginal people would (or should) have avoided, or at least not sought, contact have sought to explain the depopulation of the desert areas in terms of duress exerted by white authorities - 'round ups' designed to clear areas for various purposes and to assemble Aboriginal people at places convenient for government or

2 Cf. Kolig 1978.

3 Anon 1958:40.

4 Stanner 1960:70.

5 For general discussion of the way anthropologists and others have sought to explain the migration of Aboriginal people to settled areas see also F. Merlan. 'Flour, sugar, tea: materialism and idealism in Australian Aboriginal anthropology'. Paper prepared for biennial conference of the Australian Institute of Aboriginal Studies, Canberra, 1988. Meggitt 1962:336; Tonkinson 1974:23; 1978:130. 
ABORIGINAL HISTORY 1989 13:1

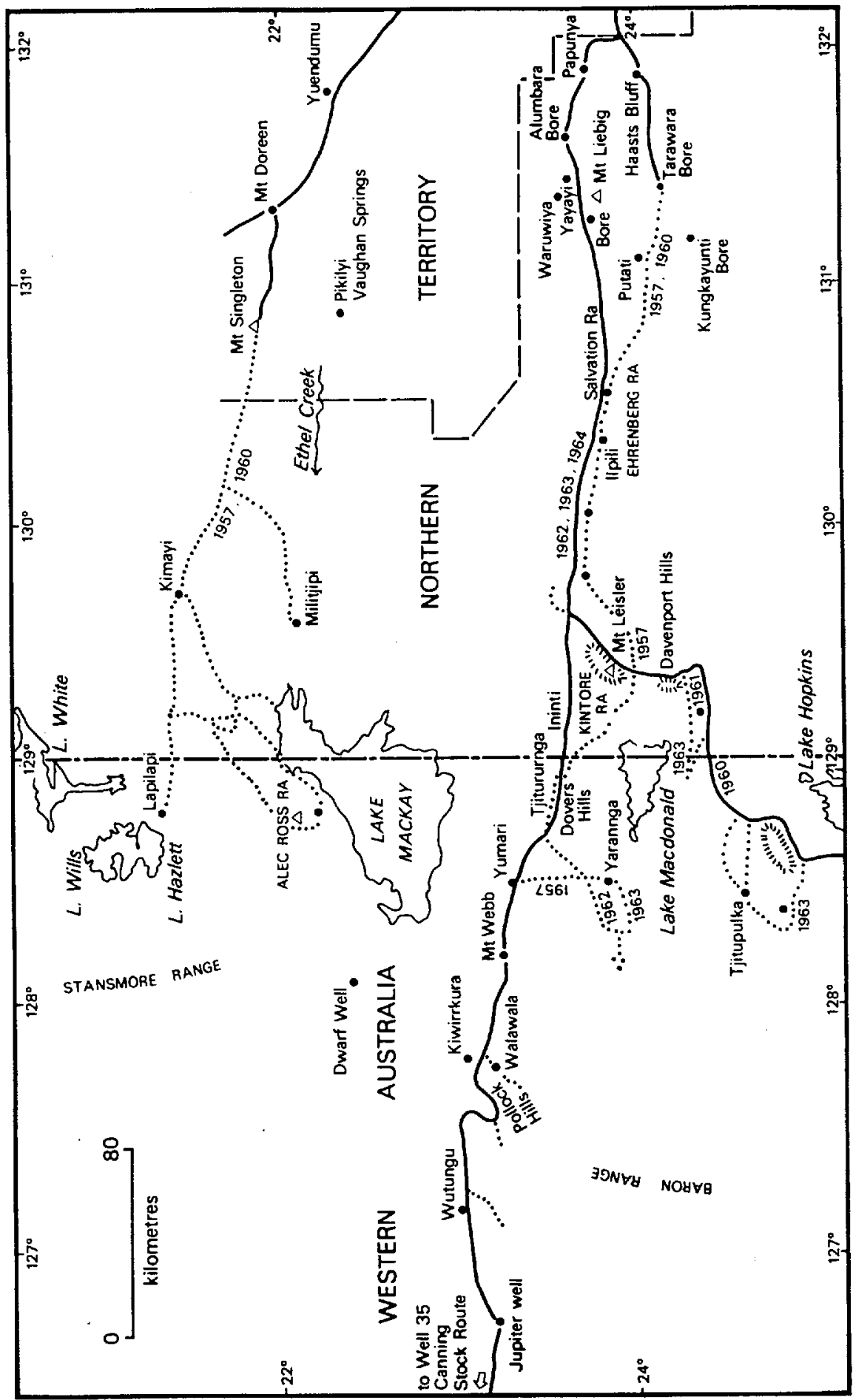

Map showing areas visited by Welfare Branch Patrols $1957-64$ [John Heywood, Cartographic Unit, RSPacS] 


\section{LEAVING THE DESERT}

missionary purposes. ${ }^{6}$ There have been a few instances of interventions by missions and governments which can be used to lend some colour of plausibility to such explanations but for the most part the facts do not fit. Everywhere it appears that emigration from unsettled areas began before any interventions by missions or governments and in many places continued in the face of active discouragement. Even the most superficial examination of the process reveals Aboriginal people as active participants, as people making choices and decisions about their lives, rather than as helpless victims. ${ }^{7}$

In different areas of the desert and of the neighbouring settled areas the history of emigration has been different. Local events and local topography have influenced the decisions taken by Aboriginal and other people and the actions of governments and other authorities. But is seems likely that, for all the local variations in the history of interaction, there may be broadly similar forces at work, encouraging or discouraging white intrusions on the one hand and Aboriginal emigration on the other.

I took part in the interaction process for a few years in one section of the long desert frontier roughly from the South Australian - Northern Territory border north to Lake Hazlett and between Papunya in the east and the Canning Stock Route in the west. The following account is therefore based in part on my own experiences and discussions with some of the Aboriginal people involved, mainly between 1957 and 1975, and on reports and papers I wrote during that time. The main focus is on the part of the region which was and is occupied by people commonly referred to as Pintupi. But I also refer to the area to the south occupied by the people whom the Pintupi refer to as Pitjapitja, who are more widely known as Pitjantjatjara and who occupy the Petermann Range and Blood's Range area of the Northern Territory. 8

\section{Early contacts.}

The first published reference to the Pintupi seems to date from 1930 when several different parties visited the eastern margin of their lands. Before then intrusions into the Pintupi lands had been few and transient. Emest Giles in 1872 and 1874 approached their territory. On his first expedition he reached and named the Ehrenberg Range at the end of September, 1872 , but, finding no water, retreated. ${ }^{9}$ These hills seem to mark the approximate eastern limit of the area used by the Pintupi. On 2 February, 1874, on his second attempt to cross the desert he rode north from the Rawlinson Range to Mt Destruction in hot summer

6 Eg P. Nathan and D. Lechleimer. Settle down country. For a critique of this approach and an interesting discussion of Aboriginal and white responses to the situations on the Northem Territory frontier, see also T. Rowse 'Aborigines as historical actors: evidence and inference' Historical Studies 22.87.

7 See also Read \& Japaljarri 1978; Kolig 1987.

8 The term Winanpa or Wenamba is sometimes applied to groups living south of Lake Macdonald and north of the Petermanns. The Warlpiri, north-eastem neighbours, tend to refer to the Pintupi as 'Bindabu' (Cf Thomson 1975:x). See also Myers 1980:28-29; Tindale 1974:23. Several accounts of Pintupi contact history have been published, notably Myers 1986:30-46, but most have been brief narratives in volumes devoted to the paintings of the Papunya school. One of them (Kimber 1988) provides a longer history, as do unpublished reports of the Department of Aboriginal Affairs (Penny et al. 1979; Kimber 1982)

Giles 1889:64-65. 
weather and again retired having lost three horses on the $50 \mathrm{~km}$. journey. ${ }^{10}$ On neither of these excursions into the margins of Pintupi country did he meet any Aboriginal people.

Colonel Egerton Warburton traversed the country of the southern Walpiri (Ngalia) in May and June, 1873, on his way from Alice Springs to the west coast. In early June he rode west into Pintupi territory south of Ethel Creek and must have been close to Lake Mackay when he turned back. ${ }^{11}$ (If his map was accurate Warburton would actually have found Lake Mackay, since it shows his course as running more than $160 \mathrm{~km}$ west of Albinia Spring. It appears, however, that in fact he travelled in a more south-westerly direction between sand ridges and probably turned back from a point about $40 \mathrm{~km}$ north of the Kintore Ranges.) He then went north and travelled through the sandridge country of the Pintupi's northern neighbours on his way westward to the Oakover River.

William Tietkens, who had been Giles' second-in-command in 1873/74 and 1875, was the first white man to travel far into the Pintupi country during his expedition of 1889 when he found and named the Kintore Range and Lake Macdonald and defined the limits of Lake Amadeus. On 17 May, 1889, Tietkens came on recently burnt country south of the Ehrenberg range and thereafter as he travelled west he saw many signs of Aboriginal occupation but did not meet any people. He found what he took to be the remains of signal fires on top of Mt Leisler and commented that 'the native population must be very small indeed, as not a vestige of a camp has been seen anywhere'. Later, when he was west of Lake Macdonald ( 6 June), he found more burnt country among the claypans and some native camps, suggesting to him that a 'large population' visited the country. For the next few days as he travelled around the south of the Lake he saw occasional 'smoke fires' but still no Aborigines. South of Davenport Hills he found a large rockhole with several camps nearby and a cave with 'idle or playful drawings'. A few kilometres farther on he found fresh tracks of three people going west and a recently built 'rain wurley'. Farther south he found more 'wurlies' near a native well and rockhole and a few days later noted fires in several directions. When he reached Lake Amadeus he noted that the country was 'not frequented by blacks'.

These first visitors were sponsored by pastoral interests and they hoped to find useful grazing lands or at least country good enough to allow stock to travel between South Australia and its Northern Territory and the colony of Western Australia. Though Giles found some attractive country farther south in the Petermann Ranges and in the ranges along the South Australian border and into Western Australia, the results of these travels were disappointing enough to ensure that no pastoral settlement was attempted and the inhabitants were left in peace by the cattle men who were taking up land in Central Australia in the 1880 s and 1890 s.

Later visitors to the desert up to 1930 , and many of those after that date, were mostly hoping to find gold. The most remarkable of these prospecting parties was led by the Hon. David Carnegie who travelled with camels and horses through some of the same country as Tietkens in May 1897. In September/October 1896 he had ridden north from the Western Australian goldfields through the spinifex-covered downs of what he called the 'Great Undulating Desert of Gravel' about 220 miles west of the Northern Territory border, on his way to Hall's Creek. On his return journey southward, after spending the hottest months resting at Hall's Creek and acquiring camels for the return trip, he travelled well to the east, skirting Lake White and, riding almost due south from Stansmore Range, passed to the west of Lake Mackay. He ventured the remarkably accurate observation that it is more than

10 Giles 1889:283-291.

11 Warburton 1875:168-173. 
probable that a large salt lake exists in this locality, possibly connecting in a broken line Lake White and Lake Macdonald'12 There at 'Dwarf Well' he met Pintupi when he came on a camp of 12 or more people and captured one of the men to lead the party to water. Again near Mt Webb (Winparrku), farther south in the heart of the Pintupi country, he met a small group of 8 or 9 people and, finding in their abandoned camp many 'message sticks', pearl shells and spears and other objects, remarked that 'certainly for its size this was the best appointed tribe we had seen'. ${ }^{13}$ Near Winnecke Hills, west of the Kintore Range, he met two women, with a dead black cat, and took one as a guide for a few miles. He found thirteen bark 'portmanteaus' in their camp and concluded that 'numerous natives must have been in this camp'. 14 He found tracks of a family near what he took to be the Davenport Hills and captured one man who led them to a nearby water. ${ }^{15}$ South and south-west of there he travelled for many days through the southern margins of Pintupi country without seeing any signs of Aboriginal people until he was near the westem end of the Rawlinson Ranges.

For many years the country apparently had few visitors. In 1913 C.H. Walker led a four-man prospecting expedition with ten camels from Alice Springs to Wiluna. Finding their way west blocked by a great salt lake (Lake Mackay), they travelled south to the Kintore Range, south-west around Lake Macdonald and then westward by way of the Baron Range on a line north of Carnegie's route. (They seem not to have had maps of Tietkens' or Carnegie's journeys and their own 'discovery' of a vast salt lake was not recorded by the official map-makers.) They encountered a group of about 30 people (probably Warlpiri) in the area of Mount Farewell and they saw fires and followed fresh tracks almost every day as they examined the Kintore Range and travelled west of Lake Macdonald. But the few people they saw fled at the sight of the party and their camels until, near the edge of Carnegie's 'undulating desert of gravel' they came upon an old woman, apparently abandoned at a rockhole, whom they supplied with bread and tea. Among the spears and other implements abandoned at one camp west of Baron Range they found 'a very old make of hatchet'. It appears that an Afghan visited the Lake Macdonald area with a camel team, hunting and trading for dingo scalps, perhaps in the 1920s. I found the leg bone of a camel at Yarangga well in 1962 and informants said that this water had been visited by an Afghan with a string of camels. Terry reports that a lone Afghan riding a camel was believed to have travelled from Wiluna in Western Australian to the telegraph line in 1904 and reported finding a large lake roughly where Lake Mackay is. ${ }^{16}$

Some of the encounters Aboriginal men and women had with travellers on these brief visits to the Pintupi country were no doubt terrifying and all were more or less disturbing, even when they avoided any direct contact. But all the contacts were fleeting and it seems unlikely that all the intrusions into the lands of the Pintupi up to 1930 had of themselves any marked effect on life in the area.

\footnotetext{
12 Ibid:393.

13 Ibid:394

14 Ibid:397.
}

15 Carnegie believed that after leaving Mt Webb he travelled to the east of Lake Macdonald but it seems that he was actually west of the Lake and that his 'Davenport Hills' were the hills now marked on maps as Turner Hills and Emery Range.

16 Terry 1934:306. 


\section{Hermannsburg Mission and the Pintupi}

But emigration of Pintupi and neighbouring groups from their desert homelands had certainly begun by the $1920 \mathrm{~s}$. The anthropologist, Geza Roheim, writing about his field work in 1929 among Aranda and Luritja people at Alice Springs and Hermannsburg referred to the 'western tribes' Pindupi, Yumu and Pitchentara, and appears to have had more than one Pintupi informant at the mission and at a ceremony held at Bowson's Hole some $50 \mathrm{kms}$ to the south-west ${ }^{17}$ When the Lutheran missionaries established themseives on the Finke River in June 1877, the Aboriginal people had been tentative in their first approaches $^{18}$ They made their first visit in August and it was a year before any women visited the mission. But by then a few men were doing some work for the mission and when in November 1879 a loading of government rations reached Hermannsburg over 100 people came and helped to consume the suddenly plentiful food. Apparently substantial numbers appeared each year after that when the annual loading of rations arrived and stayed through the Christmas period, only to leave as the rations were exhausted. Hartwig also notes that

They tended to leave the Mission in good seasons and to return in dry seasons, when, it may be assumed, they considered that the small amount of work demanded of them in return for European food would cost them less effort than securing a livelihood by traditional means. ${ }^{19}$

The missionaries were keen to attract and hold children to educate them in the Christian faith and many of the Aboriginal men were evidently hostile to these efforts. But in the $1880 \mathrm{~s}$, when Aboriginal men were spearing cattle on the neighbouring stations and themselves being pursued and shot by police and pastoralists in retaliation, the mission provided a relatively safe place for Aboriginal people to live, if not a secure refuge for men suspected of being involved in cattle killing. In the late 1880 s and early 1890 s the numbers normally living at the mission increased to about 100 of whom about one-third were at school. After the founding mission workers left in 1891 the mission was maintained by a reduced staff until Pastor Carl Strehlow arrived in October 1894 to re-establish the work and in these three years the attraction of the mission seems temporarily to have diminished. In the decades that followed the missionaries again recorded that in drought periods as in $1897 / 8$ and 1903 'Aboriginal people from outlying areas sought food and refuge at Hermannsburg' and in good seasons numbers - and school enrolments - reduced again. 20

The violent engagements between Aboriginal 'resisters' on the neighbouring Tempe Downs and Glen Helen Stations in the early 1890s had not simply reduced the local male population. It appears that people were already moving in from beyond the frontier of settlement in the 1880 s and 1890 s and the young men who came in and took to cattle killing were likely to be shot, until in the 1890 s police practice changed and more arrests were made. 21 At the same time, others were settling at these western stations and

17 Roheim 1972:141, 1974a, 1974b. Roheim identifies one Pintupi 'informant as 'Leliltukutu' who is probably the 'Liltjukurba' who three years later travelled with T.G.H. Strehlow into Pintupi country.

18 Hartwig 1965:396.

19 Hartwig:501.

20 Leske 1977:26, 29.

21 Hartwig:404-6. 
exploiting the possibilities for securing reliable food supplies in exchange for their labour, as some had been doing at Hermannsburg. When the Horn Scientific Exploring Expedition came to Tempe Downs homestead in the winter of 1894, they found 'a good number' of both 'Luritcha and Arunta Tribes' camping there. ${ }^{22}$ Farther north near Deering Creek, they came upon a gathering at a 'young men ceremony' which included some from the 'sandhill tribes from the westward' who 'declined to come into contact with white men'. ${ }^{23}$ It seems likely that by 1922 , when Pastor Strehlow died, much of the original population of the country within $150 \mathrm{~km}$ to the west had moved east to the mission, where the population reached 190 that year, and to the stations north and south-west of the mission. 24

During the 1914-18 war, the Government terminated the annual 300 pound subsidy to the mission and this must have reduced its capacity to feed and employ Aboriginal people. But the subsidy was renewed at a lower level (200 pounds a year) in July 1923 and this may have encouraged a more expansionist mood. ${ }^{25}$ In 1923 the Finke River Mission board, responsible for the Hermannsburg mission, adopted a new policy of extending its evangelical work to 'other native tribes' and of using Aboriginal evangelists in this 'spiritual outreach'. In that winter a party of 'three devoted Christians ... set out on a trip towards the west to get in touch with the Natives of the area and to explore the state of the country', ${ }^{26}$ But, by coincidence, the day before they set out a group of 37 'wild natives' came in, most of whom had not previously visited the mission station and some of whom reportedly remained there. ${ }^{27}$ It is at least possible that this party included some eastern Pintupi. (The Mission's report for the year to 30 June 1924 stated that 'twenty-seven came in from outside the station' - a substantial addition to a population of about 200). ${ }^{28}$ The mission history does not reveal how far west the 1923 party ventured, nor a second group who apparently went out in 1924, but a memorial erected near Haasts Bluff to 'Early Mission Pioneers' records that the party (August Landara, Epaphras Entamintama and Robert Palyinka) travelled 'some 200 miles west and north-west of Hermannsburg from 2.7.23 to $22.8 .23^{29}$ a distance that could have taken them well into Pintupi country. Albrecht records that the party 'took several young men back to Haasts Bluff. ${ }^{30}$ One Aboriginal informant, the late Alwin Malbangka, told me that a trip was made with camels by a party of Aboriginal evangelists from Hemannsburg before 1930 to a point west of the Kintore Range and that this party brought in quite a number of Pintupi to the Macdonnell Range country.

Evangelical trips in 1925 and 1926 seem to have been directed to groups living within the settled areas ${ }^{31}$ and in the dry years from 1927 to 1929 the mission was struggling to

\section{Spencer 1896:111.}

23 Winnecke 1897:34.

24 Strehlow considered that the bulk of the Kukatja people of the Haasts Bluff area had drifted in to Hermannsburg and Alice Springs by about 1920 (Carl Strehlow Research Foundation Newsletter 2.11, 1988).

Leske 1977:34.

26 Ibid:36.

27 Ibid:37.

28 NTA 1924:27.

29 Leske 1977:38, 48.

30 Ibid:48.

31 Ibid:38 
feed the people adequately. Scurvy broke out and was only diagnosed and checked in August 1929 , not long before relieving rains fell in December ${ }^{32}$ Again drought conditions appear to have prompted more Aboriginal people to move to the mission: two boys arrived whose mother had died on the journey in and one of them died soon after as a result of his privations. ${ }^{33}$ The movement of people from the west was an embarrassment to the mission. The mission's response to the influx in 1923 had been to adopt a policy that no able-bodied people would be taken in unless there was work for them. All others had to leave, 'to try and make a living by rabbiting, dingo scalping or working on other stations'.34

\section{Government Policies}

Up to this time the Territory Administration had demonstrated no active interest in the welfare of Aboriginal people living outside the limits of settlement, apart from declaring some lands as Aboriginal reserves. A policy of non-intervention had been generally followed from the beginning of settlement in the Territory and was the only practicable approach, given that neither administrators nor missionaries for the most part had any resources to spare for ventures into unsettled areas. The same theme was taken up from time to time by Administrators of the Territory and by their advisers. F.C. Urquhart, Administrator in 1922, wrote that

Wherever it can be done without danger or serious inconvenience to neighbouring white residents, I am of the opinion that it is best to as much as possible leave Aboriginals alone to lead their own free and natural lives until, if it is really desired to attempt their civilization, efficient agencies for the purpose are organised and set in motion.

Professor W. Baldwin Spencer, who served as Special Commissioner and Chief Protector of Aborigines in 1912, had recommended a somewhat more interventionist approach, combining the creation of large remote reserves with the appointment of superintendents to teach the Aboriginal men to engage in pastoral and agricultural work. Such reserves might not only keep the Aborigines within their territories but even induce those who had moved to the fringes of pastoral areas to return to their country. But in Central Australia he had proposed only the continued maintenance of what he referred to as the Hermannsburg reserve - actually a mission lease. ${ }^{35}$ He proposed that the area should be taken over by the Administration to 'serve as a reserve for the remnants of the southem central tribes where they can, under proper and competent control, be trained to habits of industry'. ${ }^{36}$ But these proposals were too ambitious and costly for the times and Spencer's report was set aside. 37

When the Queensland Chief Protector of Aboriginals, J.W. Bleakley, reported to the Commonwealth Government in 1928 on the condition of Aboriginals in Central and Northern Australia, the two administrative areas into which the Northem Territory was then divided, he recommended 'no unnecessary interference' with the 'nomadic tribes' living on

Ibid:46.

Ibid:46.

35 NY 1925:17.

Spencer 1913:26.

36 Ibid:26.

37 Mulvaney and Calaby, 1985:311-3. 


\section{LEAVING THE DESERT}

unalienated land. ${ }^{38} \mathrm{He}$ did, however, recommend that the South West reserve should be extended. This reserve had been created in 1920 in collaboration with the governments of Western Australia and South Australia, which at the same time had reserved large adjoining areas in those states, and covered an area of some 12,000 square miles, including the Petermann Ranges and Ayers Rock/Mt Olga.

The Aboriginal inhabitants of the south-west corner of the Territory had had rather more contact with the exploring parties looking for pastoral country in the 1870s and subsequently with scientific and mineral exploration parties than had their relatives to the north. ${ }^{39}$ The area was not far from the ranges running along the South Australian border and reaching into Western Australia, which had begun to be used each winter by men hunting dingos for the bounty, and coming both from Oodnadatta on the South Australian side and from the Western Australian goldfields. Bleakley proposed that this reserve should be extended north to the 23 degree parallel and east to longitude 132 degrees so that it would have covered most of the country occupied by the Pintupi in the Territory as well as the Haasts Bluff - Mt Liebig area. ${ }^{40} \mathrm{He}$ also suggested that some 'benevolent supervision' of the area should be provided for by encouraging the Lutheran mission at Hermannsburg to establish at least one institution in the western Petermanns near the Docker and Hull Rivers. The aim was only to provide some protection from intruders and to check on conditions during dry seasons when there might be a scarcity of water and game. He stressed that 'the aim, at the beginning, is not to draw the people away unnecessarily from their tribal life, but to win their trust by kindly ministrations, relieving them in distress or sickness and guarding them from abuse'. ${ }^{41}$ In writing these words he may have had Arnhem Land more in mind than Central Australia, but it is clear enough that the aim was to allow the people beyond the frontiers of settlement to continue living as far as possible undisturbed. He was concerned, like others, that droughts caused 'numbers of the desert blacks (to) drift to the outstation stock wells sponging upon the native well-attendants for their rations' and developing 'an appetite for the white man's luxuries'. ${ }^{42}$

\section{Prospectors and Evangelists 1930-1940}

But years passed before any action was taken to protect the Pintupi lands as Bleakley proposed, and meanwhile they had again attracted the interest of explorers and prospectors. In May and June 1930 Donald Mackay flew the first of several inland aerial surveys from a bush landing strip which his party had cleared at the Ehrenberg Ranges and 'discovered' the vast salt lake that bears his name. His party evidently met some thirty Pintupi at this camp (Mackay 1934) and identified the people they met as members of the 'Pinto and Eumo tribes' ${ }^{43}$ Later that year the same airstrip was used by the aircraft with the party searching for Lasseter's fabulous gold reef and this party was also based at Ilpili water in the Ehrenbergs. The party seems to have taken its truck as far as the Kintore Range and into the country to the south-west and Lasseter himself, with Paul Johns, later travelled with

38 Bleakley 1929:39.

39 Terry recorded that more than 80 par5ies were known to have been out to the Petermann Range 'on various quests' (Terry 1934:505).

40 Tbid:35 and map.

41 Ibid:33.

42 Ibid:33.

43 See correspondence in the Sydney Morning Herald of 30 June and 34 July 1935; Mackay named a salt lake in Western Australia Orantjugurn after 'the chief of the Pinto tribe' 
camels through the eastern and south-eastern parts of the Pintupi country on his way to and from the Petermann Range, where Lasseter died in January 1931. While Lasseter was still using Ilpili as his base a party from Hermannsburg mission arrived there in September 1930.

When the 1929 drought crisis was relieved, the Hermannsburg authorities had expressly revived the 1923 policy 'as an act of gratitude to God' and made plans 'to bring the Gospel to the nomads to the north-west of Hermannsburg' 44 At the end of August 1930 Pastor F.W.Albrecht led a party with camels north-west to Pikili (or Pikilyi : Vaughan Springs) in Warlpiri country, then south-west to Ilbilla (or Ilpili) in the Ehrenberg Ranges where they came upon the huts and airstrip made by the Mackay Exploring Expedition in the year. The group of Aboriginal people they met here had earlier been in touch with the two parties which had used this water as a base and at least the 'headman' (Kamutu Tjungarayi) had a shirt and pair of trousers. ${ }^{45}$ The party returned east by way of Potati Spring (Putati: Mt Peculiar) where they met more Aboriginal people from Haasts Bluff. For several years after this first trip parties left Hermannsburg for the north-west each winter and efforts were made to establish evangelists permanently with the group around Putati and later other natural waters.

If this initiative by the mission was motivated primarily by an earnest desire to take the message of the Gospels to the desert dwellers, it was also a response to the migration of western groups into the mission and to nearby stations. The intention was to try to halt the eastward 'drift' referred to by Bleakley. Pastor Albrecht noted that Ilbilla was 'within a great Reserve' but speculated on the likelihood that the people living there would move to the settled areas 'as many had done already' or that pastoral interests might take up the country as was then about to happen to the country around Vaughan Springs. An active interventionist policy of venturing westward to work with people 'in the bush' was conceived as having a secular protective purpose as well as an evangelical one.

In July 1932 Michael Terry, on one of his prospecting trips with camels, visited the Ehrenberg Range (Wiyanpiri: Salvation Rockhole) on his way north to make an unsuccessful attempt to explore the country north-west of Lake Mackay. He was there again in September when travelling south to the Petermann Ranges and Western Australia $^{46}$ and visited several waterholes south-west of the Range, guided for a time by Aboriginals who almost certainly included some who had visited the Mackay and Lasseter camps at Ilpili two years before. These he referred to as the 'Ilpillie-Marlu or Ti-tree scrub tribe', commenting on their friendliness to strangers. ${ }^{47}$ The following year, in a better season, he succeeded in reaching the country north-west of Lake Mackay, named the Alec Ross Range and travelled north, finding Lake Hazlett and Red Cliff Pound before going east to the Granites.

Meanwhile the Lutheran missionaries at Hermannsburg had helped to arrange for a group of Pintupi to be at Mt Liebig for the purposes of the Adelaide University anthropological expedition in August 1932. E.E. Kramer, an independent Swiss missionary in Alice Springs, supported by the Aborigines' Friends Association, Adelaide, had taken a pair of Hermannsburg evangelists out to Putati in 1931 when Pastor Albrecht fell ill and he undertook to gather Aboriginals at Mt Liebig for the University researchers.

Leske:46.

Ibid:49.

46 Terry 1937.

47 Ibid:136. 


\section{LEAVING THE DESERT}

T.G.H. Strehlow, then working in Central Australia on a research grant, went out with him on camels in June or July. Strehlow contacted the group of Pintupi who had previously been camping at Putati with the two Aboriginal evangelists from Hermannsburg (Rolf and Titus Rengkaraka) before making a camel trip west to the Kintore Range with one Pintupi guide, Lilitjukurpa. ${ }^{48}$ They met no people on the outward journey, but saw several smokes and met one small group on the return trip. Strehlow reported seeing tracks of a police party on camels which had come up from the Petermann Range area and was heading east to Alice Springs. Partly as a result of these efforts, there were some ninety Warlpiri (Ngalia), Pintupi and others at Mt Liebig when the University expedition was there in August. 49

In the space of two and a half years the eastern reaches of the Pintupi lands had been visited by several prospecting parties and by missionaries and probably by a police party more visitors than in the preceding sixty years since Ernest Giles first reached the Ehrenberg Range. Aboriginal mission workers were semi-permanently established at Putati, then at Ayantji and later at Alalpi (near Haasts Bluff) and were trying to work out a mutually satisfactory relationship with the groups with whom they lived. The evangelists had to be rationed to live at these outposts but the Aboriginal people expected them to share their food with them while it lasted. The cumulative effect of all these friendly contacts and in particular the continuing contacts with Hermannsburg, seems to have prompted several more Pintupi families to move eastward to settle in the Haasts Bluff/Mt Liebig area or to move on to the Tempe Downs and Glen Helen cattle stations and Hermannsburg mission. Possibly in response to these intrusions, the Chief Protector of Aborigines, Dr Cecil Cook, revived the proposal to extend the South-west reserve in December 1932 and in March 1933 his recommended sixty kilometre wide addition, including the Kintore and Ehrenberg ranges, was gazetted. ${ }^{50}$ But it was not extended eastward to include the Haasts Bluff area because this was held under lease and grazing licences. 51

At least by 1935 , the Hermannsburg evangelists were encouraging these western people to believe that if they responded to Christian teaching, there would one day be a station like Hermannsburg established near Haasts Bluff where their children could be educated, the old and sick cared for and no one need go hungry. ${ }^{52}$ Reporting on his visit to the camp that winter, Albrecht recorded that he had been told that the Pintupi feared to return westward. Their relatives out there thought they had killed a young man who was said to have been taken in to Alice Springs by an Afghan dogger visiting the Kintore Range some years earlier. ${ }^{53}$ On the annual visit in 1936, this time with a motor car to supplement the camels, Pastor Albrecht estimated that his party contacted groups totalling nearly 300 people in the area between Haasts Bluff, Mt Wedge and Mt Liebig. ${ }^{54}$ But early the next year Albrecht learnt of plans for the Haasts Bluff country to be stocked with sheep under grazing licence. ${ }^{55}$ His vehement protests, supported by Dr Charles Duguid of Adelaide,

48 Strehlow, personal correspondence 1964.

49 Fry 1934.

50 AA/FI.38/418).

51 Ibid.

52 Leske 1977:53.

53 Albrecht 1935.

54 Ibid:53.

55 It appears that a cattle station had earlier been established in the Haasts Bluff area for a few years around 1911 (R.G. Kimber, personal communication 1987; Albrecht 1935). 
who had accompanied Albrecht on his annual inspection visit to the Haasts Bluff area in 1936, were effective in persuading the Federal Minister to order that the grazing licences should not be renewed and that the Haasts Bluff area should be left to the desert people who had moved there. 56

\section{Haasts Bluff Reserve and Ration Depots 1940-50}

Government concern about the movement of 'western' people towards Alice Springs evidently made it relatively receptive both to the 1937 proposal to exclude graziers from the Haasts Bluff area and to proposals developed in 1939, on the basis of the reports prepared by Strehlow who was appointed as patrol officer for Central Australia from October 1936, to reduce the area of the South-West Reserve and create a new Haasts Bluff reserve in the north east. The northern part of the 1920 Reserve was revoked in October 1940 on the basis that this was 'country useless to natives' and instead 'food-producing and adequately watered areas adjoining the north-east corner of the Reserve as far as and including Haast's (sic) Bluff were reserved - an area of some 7636 square miles. ${ }^{57}$ This entailed buying back the Haasts Bluff lease and the solitary improvement on it - a well at Alalpi - at a cost of fifty pounds. The new Reserve adjoined the mission lease and pastoral leases on the east and extended south to Lake Amadeus but did not reach as far west as the Ehrenberg Ranges, so that the country of the Pintupi in the Northern Territory was again unprotected.

Reports that dry conditions in October 1940 were prompting some of the people in the Haasts Bluff area to move east to outcamps on Glen Helen station helped the Hermannsburg mission to win early approval in 1941 to establish and maintain a ration depot at Ngankeritara soak, south of the Haasts Bluff range, with Government subsidies to cover the costs of erecting a store, employing a storekeeper, rationing the aged and infirm at $3 / 8$ per week each and supervising the operation. ${ }^{58}$ When the first rations were distributed in April 1941, Strehlow listed 65 aged and infirm people as eligible for rationing, but there were many more than this in the area. ${ }^{59}$ A list of Aborigines at Haasts Bluff in October 1942 records 71 males, 85 females and 90 children, a total of 263 people. It seems likely that about 90 to 100 of these were Pintupi at this time and the others were Warlpiri from the north-west, Kukatja from the western MacDonnell Ranges and a few families from the south-western country.

The storekeeper employed at Haasts Bluff by the mission, Theodor Abbott, held cash to pay men for dingo scalps, kangaroo skins and 'curios' as well as rations for the women and children and aged and infirm. ${ }^{60}$ Although only about half the men and not all the women who were in touch with his store were actually rationed, the services available were evidently attractive enough to hold a substantial group in the Haasts Bluff area and possibly to persuade some who had moved east to Alice Springs to move back. But word of the new ration depot may have taken some time to reach people in the west who had not already been in touch with the Hermannsburg evangelists. Already by 1942 it appears that a wide expanse of uninhabited country had opened up between Haasts Bluff/Mt Liebig and the Western Australian border country.

\footnotetext{
56 Leske 1977:54.

57 NT 1940:30.

58 AAF126.30; Leske 1977:55.

59 AAF126.30.

60 Leske 1977:55-56.
} 


\section{LEAVING THE DESERT}

Before the Haasts Bluff depot had been established for many months official concern about Aboriginal people congregating at the railway sidings south of Alice Springs led to a request to the mission authorities in 1942 for another ration depot to be set up to halt and perhaps reverse the eastward movement in the area south of the Macdonnell Ranges. ${ }^{61} \mathrm{~A}$ spring in a narrow valley in the Krichauff Ranges south- west of Hermannsburg was chosen as a convenient site and a gang of men set to work to make an access track. The government dumped stores for the new Areyonga depot at Hermannsburg and later improved the creek crossings so that supplies could be trucked in rather than carried by camel team. The mission history records that the news spread quickly and people soon arrived, grateful that special provision was being made for their needs. These apparently included some people whom Pastor Albrecht had seen in the Petermann Ranges when he travelled there with Patrol Officer Strehlow, in 1939.62

Both there and at Haasts Bluff, water shortages soon became a problem as the population grew. As early as August 1941 Pastor Albrecht was recommending that bores or dams should be provided at several different places near the Haasts Bluff depot so that people could continue their foraging life as long as possible. ${ }^{63}$ By 1946 there were 238 people at Haasts Bluff and 93 at Areyonga and bores had to be sunk to provide reliable supplies at both depots. Bores were also sunk at three other sites on the Haasts Bluff reserve to allow the country to be stocked. ${ }^{64}$ By 1948 vegetable gardens had been established and several buildings erected, including a church at Haasts Bluff in 1946 and a house for a missionary who took up duty there in June 1947, with his wife who was a nursing sister. ${ }^{65}$

There was some modest development of the two depots over the next seven years and some increase in Aboriginal employment but essentially the rationing scheme remained the same until, in 1954, the Northern Territory Administration assumed direct responsibility for both places and began to invest more money in their development and to provide work for the able- bodied males and some women. Mr L.G. Wilson, who had earlier been recruited by the mission to supervise the Haasts Bluff cattle herd, became manager of the settlement there and more cattle bores were sunk north of the range. But already, in the winter of 1952 , Wilson had developed a scheme for 'dispersing the native population to several springs on the reserve'. 66 'The Pintupi Tribe' he reported 'have requested to settle at Walimbury Spring (later referred to as Alumbaru) a distance of 50 miles from the settlement by road' and about 70 were living there when the fortnightly delivery of rations was made in midJuly. ${ }^{67}$ Another camp was soon established at Unabuna and later a group of stockmen and several dingo hunters were camped at Mt Liebig bore. This practice was applauded as 'good policy' by the Native Affairs Branch District Superintendent in Alice Springs. ${ }^{68}$ Taking rations out to dispersed groups to some extent counteracted the centralising pull of the

62

Leske 1977:60; NTA 1946:28.

63 AA/F126/30.

64 NTA1946:28.

65 Leske 1977:57.

66 AA F1/52/440.

67 Ibid.

68 Ibid. 
ration depot and restored something resembling the pattern of living that had prevailed in the ten years before the depot was established.

\section{Welfare Settlements}

The government take-over of Haasts Bluff (and Areyonga) reflected the new, more positive and interventionist approach of the N.T. Administration under the direction of $\mathrm{Mr}$ (later Sir) Paul Hasluck who had been appointed Minister for Territories in 1951. More money was available to the Native Affairs Branch, which became the Welfare Branch in 1953 , in order to develop employment, training, education and health services on the settlements.

At Haasts Bluff the immediate changes were few: an assistant was appointed to take care of the cattle work and more fencing, yard building and other developmental work meant more jobs but the 'dispersal policy' was maintained for several years and the Pintupi group continued to spend at least a part of each year away from Haasts Bluff, camping at bores or natural waters. But when the water supply at Haasts Bluff was found to have deteriorated and to have a high content of sulphates and fluoride, the decision was taken to develop a new settlement north of the range at the Papunya bore where there was abundant water of good quality. During the construction period (1957-9) workers and some others chose to camp there but Haasts Bluff remained the rationing centre for the more than 400 people then settled on the reserve.

In the late 1940 s and 1950 s more families had continued to walk in to the Haasts Bluff/Mt Liebig area from the west but some - probably young men and boys for the most part - had also returned to the west on occasions. One man (Bruno Tjangala) told me that he had been to Haasts Bluff as a boy but had gone out again and been initiated about 100 kms beyond the Western Australian border, probably in the early 1940s, and had returned to Haasts Bluff only in 1956. These men would have carried news of the ration depot to their relatives, as would the men who accompanied a prospecting party, led by Mr James Prince, which went out with camels and trucks in January 1947. Five Aboriginal men accompanied the party which travelled west past the Kintore Range and Lake Macdonald, then south to Tjila well and the Rawlinson Range, meeting at least two groups of Pintupi in the country south of Lake Macdonald. Because the mission storekeeper did not ration able- bodied men but did trade dingo scalps, there was some incentive for men to make journeys to the west to procure scalps and at least some of these seem to have ventured to and beyond the Kintore Range.

In 1956 a dogging party of three men from Haasts Bluff (of whom only Charlie Tjaruru Tjungurrayi survives at the time of writing), went out with camels and met relatives near the Western Australian border. They had a significantly different tale to tell of life at Haasts Bluff. There were rations for all, not just for the old and infirm and women with children; there was work and a small cash wage for all who wanted work; free issues of clothing and blankets were made regularly; and the growing cattle herd provided fresh meat every week for all. Where previously married men might have concluded that they were marginally better off in touch with the depot than maintaining an independent existence in the desert, there was by 1956 no question that life would be more secure and families better nourished at Haasts Bluff. When the doggers told their relatives of 'flour, tea and sugar, trousers and shirt' and urged them to come in, it was a distinctly new message, reporting a significant change for the better in what Haasts Bluff had to offer. The response seems to have been enthusiastic: two men walked quickly to summon others camped farther south, west of Lake Macdonald, and together the camel men and some nine families set off for Haasts Bluff. A party of some 34 people reached Haasts Bluff in December 1956 from the west. 
More had set out but several turned back from the Ehrenberg Ranges, deterred by the privations of the long walk through unfamiliar country in a dry summer. One woman died at a bore only $20 \mathrm{kms}$ from Haasts Bluff. Those who survived the long walk in were found to be in poor condition: 'many ... were undernourished, had respiratory signs, and more severe trachoma; two of them had tuberculosis, and many others radiological evidence of respiratory disease'. ${ }^{69}$ In November and December 1956 the settlement had reported an outbreak of pneumonia, apparently before the immigrants had arrived, but in the Manager's report for May 1957 he noted that there was still 'a little Dysentery and Pneumonia about, introduced when the Pintubi mob came in from bush last December'. ${ }^{70}$ The tuberculosis cases were closely watched but by July it was noted that 'the general health of the Pintubi people who came into Haasts Bluff last Christmas . . . has considerably improved'. ${ }^{71}$ An influenza epidemic struck the settlement in September but there were no fatalities among the recent arrivals.

At about the same time other groups were making similar trips elsewhere around the desert rim. It appears that groups came in to Cundeelee mission east of Kalgoorlie, to the Warburton Range Mission, to Christmas Creek station in the Kimberley region and to Balgo Hills mission in 1955 and 1956. The years 1952 to 1955 were not unusually dry in Central Australia and drought does not seem to have prompted these moves. In 1955 some press publicity was given to reports that small parties from the west were coming in to $\mathrm{Mt}$ Doreen Station, some $160 \mathrm{kms}$ north of Haasts Bluff. Welfare Branch officers in Alice Springs spoke to some of the men and to the lessee of the station, $\mathrm{Mr} \mathrm{W.W.} \mathrm{Braitling,} \mathrm{who}$ reportedly attributed these visits to the fact that the desert people had become 'lonely and (had) lost contact with what is going on around them'. ${ }^{72}$ They proposed sending out a party to check on the health and the needs of the people living between Mt Doreen Station and Lake Mackay, and to report on the possibility of providing supplementary water supplies and on the development potential of the area. Shortage of field staff in 1955 and 1956 meant that the patrol was postponed but the proposal gained some political momentum when public controversy erupted late in 1956 over claims in the Western Australian parliament that Aboriginal people were starving in the country around the Warburton mission and the recently established Giles Weather Station.

\footnotetext{
69 Hargrave 1957.

70 AAF1.55/382.

71 Ibid.

72 AA/F 1.55320.
} 


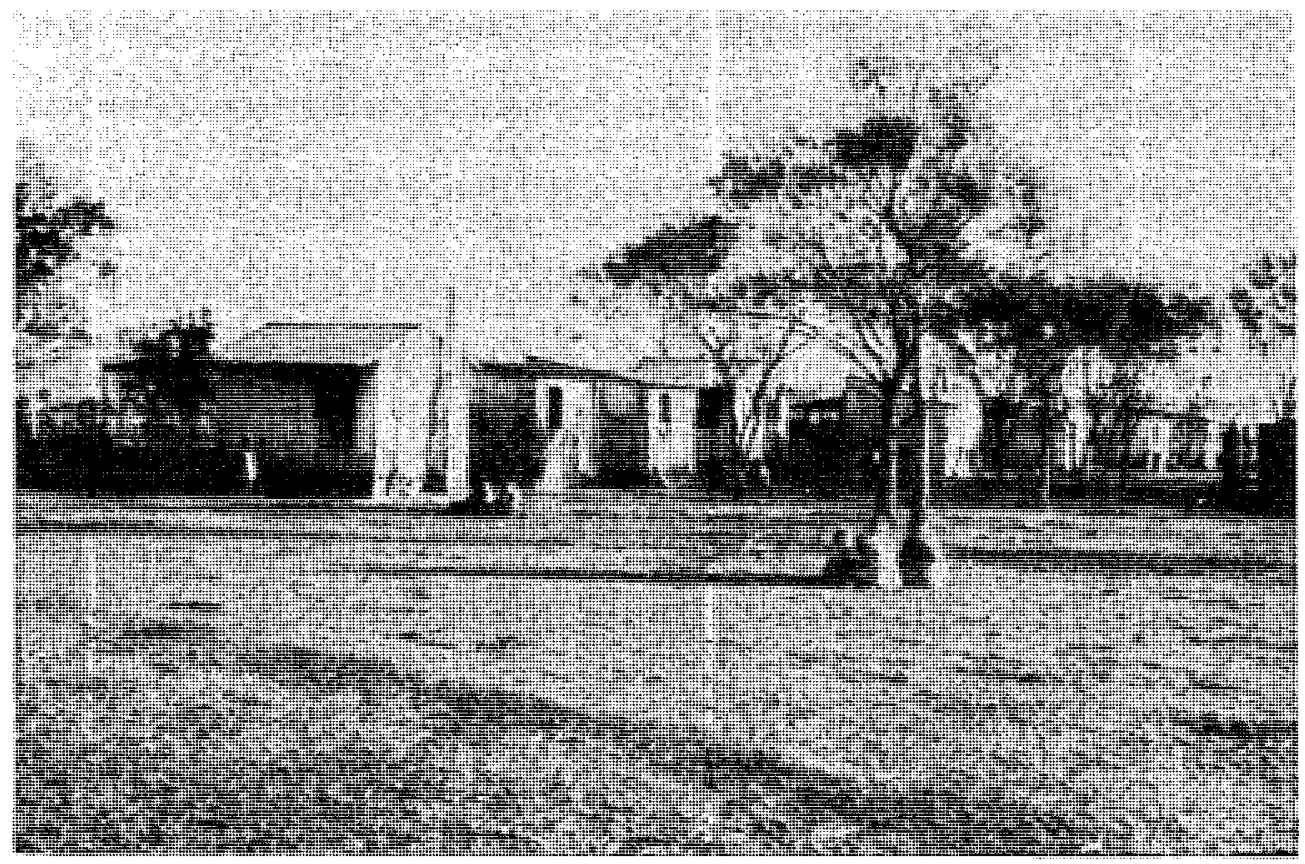

Above: Row of huts at Haasts Bluff, built by the Finke River missionaries, c.1948. The houses were possibly intended as houses for the sick, but were probably occupied by Aboriginal mission staff.

Below: Digging out Alalbi well, 1958, a few miles east of Haasts Bluff. The well and the leasehold improvements were the only compensation received by the holder when the reserve was resumed. (Photograph by Jeremy Long)

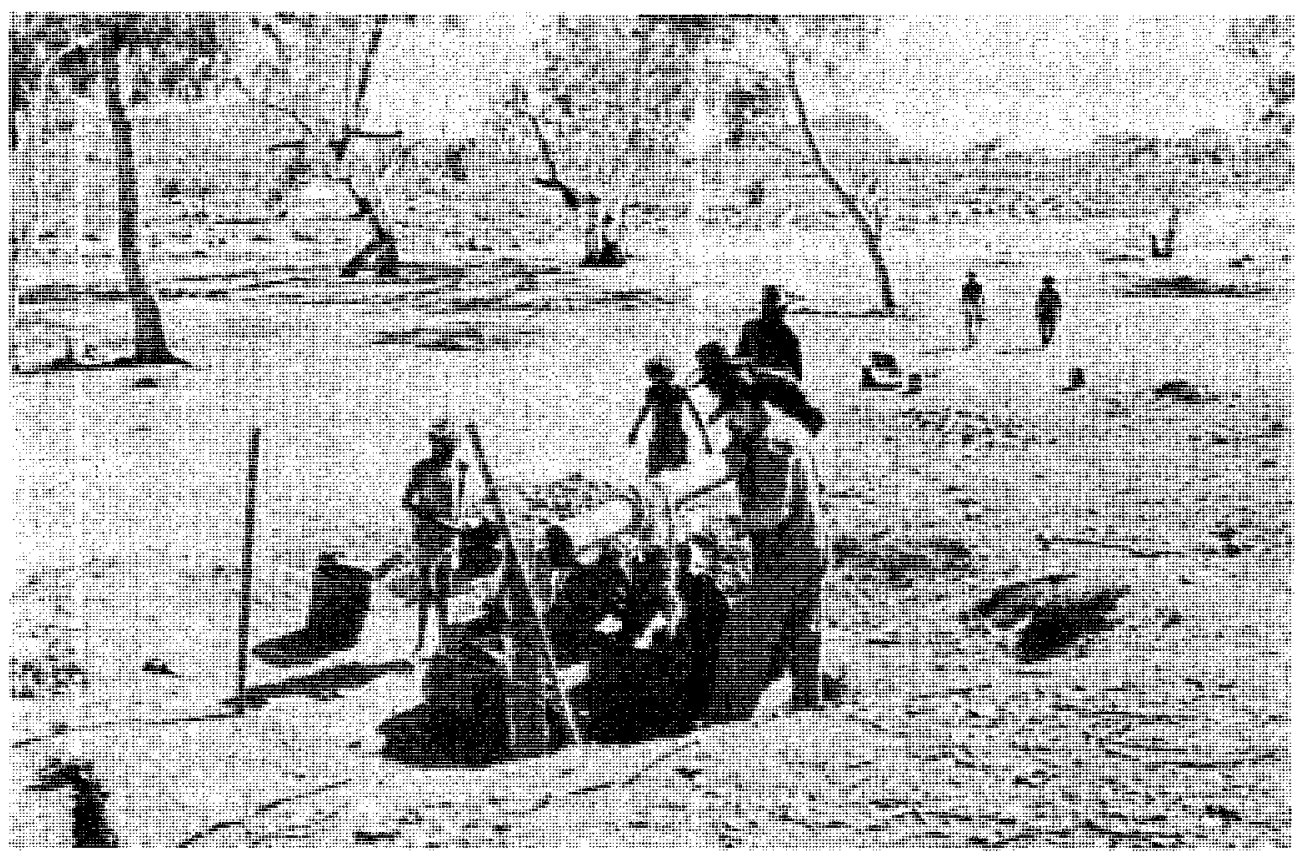


Lake Mackay and Kintore Range Patrols.

The expedition was finally undertaken in June $1957 .{ }^{73}$ It was led by Mr E.C. Evans, Chief Welfare Officer with the Welfare Branch, NT Administration, who was accompanied by the author, then a Cadet Patrol Officer with the Welfare Branch; Dr John Hargrave, Medical Officer, Department of Health; Mr N. Jones, Geologist, Bureau of Mineral Resources; Mr G. Chippendale, Botanist, Animal Industry Branch, NT Administration and an assistant; and $\mathrm{Mr} \mathrm{T}$. Cooper, Driver, NT Administration. Mr W. Braitling of Mt Doreen Station accompanied the patrol in his own vehicle. Two men who had lately walked in to Mt Doreen guided the party back to their families, a group of 20 people, who were met at a small well about 30 miles east of Lake Mackay. A second group of 22 people was found south of Alec Ross Range on the other side of the lake. ${ }^{74}$ These groups were living 150-200 kms away from Mt Doreen station and only one of the western group had previously made the journey there. Members of the first and closer group had visited Balgo Hills mission as well as Mt Doreen but had chosen 'to return to the bush'. ${ }^{75}$ The patrol was accompanied by Dr Donald Thomson of Melbourne University who planned to spend some months with one of the groups to study their pattern of life but our report sounded a cautious note about the likely effect of the visit on the people:

It is difficult to judge what the effect of recent intrusions by parties of whites will be. Already one group has attached itself to Dr Donald Thomson (Melbourne University) and the other will probably also test his hospitality. It is his intention to avoid disrupting their way of life and he hopes to move about with them on foot to study their normal routine, but such an intention must be difficult for the Pintupi to understand. They no doubt hope to camp with him to share his supplies for as long as possible. When Dr Thomson leaves the area, the Pintupi may revert to their normal way of life, but one man expressed his intention of visiting Mt Doreen and Yuendumu Settlement again in the near future and others may follow Dr Thomson in to Mt Doreen.

Every effort was made to ensure that the impression was not given that the Administration wanted these people to leave their country and come into Mt. Doreen or to a settlement. There is, however, no guarantee that this and other misleading information was not provided by our interpreters. 76

Our personal views about the desirable future of these people are manifest in the findings and recommendations we made. The people were found to be in good health with access to adequate food but only few and meagre water supplies. The country visited had 'almost negligible' pastoral potential and there was no evidence of any mineral deposits of value. We proposed that the area south of the 21st parallel of latitude, lying west of the Mt Doreen pastoral lease and of the existing Haasts Bluff Reserve as far south as the Southwest Reserve should be declared a reserve and a matching area north of the existing Central Reserve in Western Australia similarly set aside by the authorities in that State. The expressed aim was to allow for contact to be 'controlled and supervised' to avoid disturbance

73 For more contemporary accounts of this and the subsequent patrols up to 1964 see J.P.M. Long 'The Pintupi patrols: welfare work with desert Aborigines' Australian Territories 4(5):43-8, (6):24-35; and E.C. Evans and J.P.M. Long 'The Aborigines of western central Australia' Geographical Journal 131:318-29.

Evans 1957.

Ibid.

Ibid. 
of their way of living and the introduction of diseases. We made no proposals for sinking bores or wells in the area, partly because the heavy rains that fell during the patrol's visit had relieved any immediate shortages. We also recommended that another patrol should be made to the Kintore Range west of Haasts Bluff 'to ascertain the number and condition of the Pintupi inhabitants' and that an annual patrol be made to revisit the Lake Mackay area to 'observe the condition of the people' and maintain contact. 77

At the end of October 1957 a very much smaller party - two patrol officers (the author and Colin McLeod), with a mechanic and two guides ('Nosepeg' Tjupurula and Tapatapa Tjangala) - left Haasts Bluff for the Kintore Range area. The weather was hot and water shortages forced a detour south of the Range but in four days we had reached the Western Australian border without finding any signs of recent occupation of the area or any response to the 'smokes' put up by our guides. ${ }^{78}$ The next day we did see a smoke and met a group two men and their families - about $45 \mathrm{kms}$ west of the border, at Yarannga well, north-west of Lake Macdonald. Visiting another water (Yumari) about $60 \mathrm{kms}$ to the north, we saw a smoke some distance away to the south west but decided against travelling farther west and started back to Haasts Bluff, bringing with us the young man (Tim Tjapangati) we had met who was keen to visit his mother and other relatives at Haasts Bluff. (I took him back to rejoin his family in June 1958 when a National Mapping party went out to Lake Macdonald. He brought his wife and child back to Haasts Bluff later in the year and another man (Pinta-pinta Tjapanangka) also walked in with his family before the end of 1958.) The few people seen at Yarannga ( 4 adults and 3 children) also seemed in good health.

We proposed that another patrol should be made with a medical officer in about April 1958 and that similar short patrols should be made each year. Although the two patrols had found that the country in the Northern Territory was mostly unoccupied we suggested that the NT Administration should continue to take an interest in these people whose relatives had moved in to Haasts Bluff. During and after the patrol I compiled a list of families known to be living in the 'Pintupi country', totalling 56 adults and 44 children, apart from those met during the two patrols. I noted that all of the previous year's immigrants 'would like to return to their country, but the older people were aware that it is beyond them and only the young men . . . are likely to make the return journey'. ${ }^{79}$ My report went on to suggest that:

The Pintupi could best be served at present by the sinking of bores to provide reliable waters, capable not only of meeting their drinking water needs but also to provide water for the camels of the dingo hunters and possibly for a few cattle to supplement natural game. ${ }^{80}$

I noted that the Pintupi, who made up the bulk of the population at Haasts Bluff, do not like living at the settlement and are keen to return to their own country if the Administration would assist them and live there and develop it. ${ }^{81}$

By early June 1958, when I visited Mt Doreen Station, most of the people we had seen twelve months before near Lake Mackay, along with some young men we had not seen then, were camping near Mt Singleton, at a waterhole at the western edge of the property. Some had been for a few weeks with Dr Thomson in the Labbi-labbi area but after he had

78 Ibid.

78 Long 1957.

79 Ibid.

80 Ibid.

81 Ibid. 


\section{LEAVING THE DESERT}

left in October most had moved east. Three young men took the opportunity to visit their relatives at Haasts Bluff for a few weeks.

In September 1959 the enlarged reserve (R.1028) recommended in the 1957 patrol report was created, incorporating the former South-west and Haasts Bluff reserves. The Western Australian authorities extended the reserves in that State, linking the Central Reserve near Warburton with the Balgo Hills reserve.

When a second patrol visited to the Lake Mackay area in July 1960, again led by Evans, the party met a group of 7 adults and 2 children walking back in to the station and later met two families (11 people) north of Lake Mackay. Evans was told of, but did not meet, two other small groups in the area. 82 After questioning his guides about the apparent depopulation of the area, Evans concluded that 'owing to the series of dry years, the smaller game ... have virtually died out or have been so depleted in numbers as to no longer maintain the people in their meat needs'. He was also told that a large group had gone to Balgo Hills Mission.

The party then travelled to Papunya and followed the tracks of the 1957 patrol to the Kintore Range where they came upon a freshly graded track cut from the south by a Department of Supply roadmaking party. Distant smokes were seen one day but there was no response to the party's own 'smokes' at Lake Macdonald and Dovers Hills and they left to follow the new road south to the Giles Weather station in the Rawlinson Range. Diverting to Tjukula and Tjila wells near Lake Hopkins they met a group of four young men who had had some contact with the Warburton Mission, with Giles and with the Native Patrol Officers appointed by the Department of Supply who by then had been regularly patrolling the Petermann/Rawlinson Range area for some years.

By the end of 1960 most of the people seen in the Lake Mackay area in 1957 and in 1960 had moved in to Mt Doreen Station. Inquiries of these people indicated that six men, and 'probably no more than a dozen or fifteen in all' remained out in the Labbi-labbi area. The station owner provided rations at Government expense to those who had moved in but conditions there were rather less attractive than at the nearby Government Settlement, Yuendumu, or at Papunya and this might account in part for the fact that some had retumed from Mt Doreen to the desert when rain fell. But it also seems that they returned to find their relatives and encourage them to come in. ${ }^{83}$ The Superintendent at Yuendumu was, by late 1960, proposing that the 'Bindubi' at Mt Doreen should be encouraged to move to Yuendumu where they could be better looked after and be provided with useful work. Within a few months most had moved to Yuendumu where the men were formed into a special gang quarrying local stone to build houses. By 1963 they had been joined by most of those who in 1960 had been recorded as still out near Labbi-labbi and most of these immigrants remained at Yuendumu for the next ten years or so.

When, in the 1970s, with increased incomes and access to vehicles, these people were able to visit relatives at the Balgo Hills mission some moved there for varying periods; some settled at an outstation (Nyirrpi) on Waite Creek to the southwest of Yuendumu; and others joined their relatives at Papunya in later moves westward to the Kintore Range and beyond when bores were finally sunk in Pintupi country.

Meanwhile the making of the Department of Supply (Weapons Research Establishment) road north from Giles, east to Mt Liebig and west towards the Canning Stock Route had, by the end of 1960 , made access much easier to the other areas which

\footnotetext{
82 Evans 1960.

83 R.G. Kimber, personal communication 1987.
} 
were known to be inhabited. Between June and September 1961 the new road west from Mt Liebig was used by a National Mapping party which sunk a well in limestone country at the end of the graded track, some $600 \mathrm{kms}$ west of Papunya and called it 'Jupiter Well', using it as a base for survey work as far as Well 35 on the Canning Stock Route. (In later years this track beyond Jupiter Well was graded and the network was extended to link up with the Western Australian road system.) Although Aboriginal people seem to have kept clear of the road making party in 1960, some certainly came in to the camps of the survey teams the following year, presumably obtaining some food from the party and certainly acquiring cans and other useful metal items.

In August 1961, after attending a meeting in Alice Springs of the Central Reserves Committee, a group of Commonwealth and State officials concerned with the administration of the adjoining reserves in South Australia, Western Australia and the Northern Territory, I travelled with one of the two WRE patrol officers (Mr R.A. Macaulay) along the new road from Mt Liebig to Sandy Blight Junction and south to Giles. Southeast of Lake Macdonald we found tracks on the road in dense sandhill country and met four members of a family (of ten) who usually lived in the country farther south nearer to the Rawlinson Range. After this trip I proposed regular visits to the Lake Macdonald area and a short patrol to examine the Petermann Range country and gather more information about the extent to which it was inhabited.

\section{Reoccupying the Petermann Range}

Earlier in the month I had visited Areyonga as a research officer with the Welfare Branch to study the 'movements and rate of growth' of the population there. Noting that the great majority originated in the Petermann Range country and that the prospects for development at and near Areyonga were distinctly limited, I suggested consideration of the idea, originally advanced in 1928 by Bleakley, that some services for Aboriginal people be provided in the Petermanns:

As a possible part-solution to the problem the opening up of the Petermann

Range country immediately suggests itself or rather the Areyonga people, with

the usual enthusiasm of natives for their country of origin, suggest it. ${ }^{84}$

People from the Petermann Range area had begun moving east into the cattle country well before 1930 and the existence of the South-west reserve had no discernible effect on this drift. A fairly rapid depopulation of the Petermann Range seems to have followed in the 1930s, and in 1937 Strehlow commented that in the previous ten years there had been 'a flight or a rout rather than a drift' from the Petermanns and that the northern part, 'the old territory of the Pintubi, seemed to be quite empty'. ${ }^{85}$ The Chief Protector, Dr Cecil Cook, reported in 1937 on the 'increased number of far western natives coming into Alice Springs' and noted that this movement was considered to be prompted by 'semi-civilized natives travelling about the South-westem Reserve collecting dingo scalps for white employers, and disseminating among the inhabitants glowing stories of the attractions of the settled areas' ${ }^{86}$ But there were also several white doggers, some of them holders of pastoral leases in the country south-west of Alice Springs, who regularly ventured into the Ranges trading scalps in the 1930s. A Board of Inquiry in 1935 had examined allegations about the illtreatment of Aboriginals in Central Australia by police and made recommendations, among 


\section{LEAVING THE DESERT}

others, for the appointment of a patrol officer to take responsibility in particular for the South-west reserve and for the establishment of a 'Govemment Aboriginal Station' there. ${ }^{87}$ Strehlow's 1937 recommendation for a 'trading depot' in the heart of the Petermann Range in order to entice the former inhabitants to return was evidently set aside because of the considerable costs involved 88

Two years later, after a second patrol, Strehlow reported the reserve 'virtually empty' with an estimated fifty or sixty still living there, though he actually met just 26 men, women and children on this trip ${ }^{89}$ (He reported meeting a young man who had returned to the Ranges after visiting Hermannsburg and Haasts Bluff the year before and a young woman who had been at Jay Creek for several months in 1938: not all the journeys from the west were one-way trips.) He seemed to attribute this depopulation in part at least to a series of dry years which had depleted the area of game. He offered no other explanation of 'hundreds of homeless Reserve natives... wandering about aimlessly in the vicinity of Alice Springs, Finke Siding, Hamilton Bore, Middleton Ponds and Kings Creek'. One need not, however, assume that he considered the 'push factor' of poor seasons the only or even the main reason for movement.

In 1939 Strehlow again recommended the establishment of a depot in the western Petermanns and he was confident enough about this proposal being acted upon to be discussing the cutting of a motor track from Hermannsburg to Ayers Rock and on to the Petermanns in order that a base may be developed in the Petermanns before the middle of summer. ${ }^{90}$ But this proposal too was shelved and only the less costly depots at Haasts Bluff and Areyonga were proceeded with in the early 1940s. After the war, a patrol officer of the Native Affairs Branch (Mr John Bray), who was sent out to the Petermann Range in January 1951 with a party examining the mineral potential of the area and another Administration party, which visited the Ranges in 1958 in a joint examination of the Central reserves with South Australian officers, both recommended that services for Aboriginal people should be provided there but no action had been taken.

In mid-September 1961, with a patrol officer, Mr John Hunter, and two guides from Areyonga (Tjingu-nya and Ernest Tjuku), travelling in one Landrover, I spent nine days exploring the Ranges. We met members of one group of 19 'Rawlinson people' at Wanggarin, a rockhole on the south side of the Ranges near the Western Australian border. 91 The country was drought- stricken and most waters visited were dry or had only meagre supplies. But my report stressed that there were extensive areas with potential for cattle grazing and strongly urged that efforts be made without delay to find underground water supplies which might allow 'a first trading-post-cum- cattle station' to be established near the Docker River. The existing track from Mt Olga provided easy access for investigational boring near the creeks running out on the north of the range but it was urged that 'outstations should be established early, south of the Range and towards the eastern end near Irving Creek' 92

87 Ibid:24.

88 AA/FI38/418.

89 Strehlow 1939.

90 AA F31.32/3.

91 Long 1961.

92 Ibid:4. Memorandum Long/Evans, March 1961: I was then employed with the Welfare Branch as a research officer (1960-1968) after having been stationed as Superintendent at Haasts Bluff (1958) and spending most of 1959 and 1960 outside the Northern Territory. 
These proposals were supported by the Administration in Darwin and accepted in Canberra and in April 1963 I was again in the Ranges with a geologist and a Water Resources Branch boring supervisor to help select exploratory boring sites for drilling. Adequate supplies were found later that year and in due course bores were equipped. In September 1967 a patrol officer and a gang of seven men from Areyonga went out to work on clearing an airstrip, by December families began to move out and by June 1968 there were 75 Aboriginal people at Docker River. ${ }^{93}$ The writer of the first report on the 'welfare centre' at Docker River recorded that 'some of the old men were exuberant at being able to return'.94

They had certainly had a long wait. The depopulation of the Ranges was, it seems, well advanced when Bleakley had suggested in 1928 that an 'institution' might usefully be established near the Docker and Hull Rivers in the South west or Lake Amadeus Reserve and was practically complete when Strehlow urged action in 1937 and 1939 . No one having any prolonged dealings with people from the Ranges in the forty years that followed Bleakley's proposal could have doubted their enthusiasm for a return to their homelands. But only in the 1960 s was government ready or able to respond.

Essentially the difference then was that unprecedented money was being spent by government on Aboriginal development and welfare and what might have seemed an impossible extravagance for an impoverished administration in 1928 or 1939 was an interesting possibility in 1961. By then the development of long established and newly resited settlements had been proceeding rapidly for some years. The limitations of the Areyonga site with its poor water supply and restricted area were apparent to all and welfare administrators in Darwin were ready to respond to suggestions that land in the Petermanns was waiting to be developed for cattle raising projects and perhaps small- scale market gardening. They had also been concerned for some years about the poor impression given to the steadily increasing number of visitors to Ayers Rock by the groups of Aboriginal people who spent the months from about May to September each year at Angas Downs and sometimes Curtin Springs, selling artifacts, posing for photographs and begging from tourists. Officials were concerned that their children were missing school, that housing and other facilities would not be provided for them and that they had no medical services. The possibility that an outpost in the Petermann might attract at least some of these people from the Ayers Rock road had considerable appeal. For all these reasons there was solid support for the idea of directing some resources to the search for suitable water supplies and to the provision of at least minimal services in the western Petermanns. The six years or so it took from the revival of the proposal in 1961 until Pitjantjatjara people were able to begin moving back at the end of 1967 was a much shorter wait than their northern neighbours experienced in having water supplies provided in their lands.

\section{Pintupi Patrols 1962-64}

The suggestion I made in August 1961 that the new road access to the inhabited country west of Lake Macdonald should be used for yearly visits by patrol officers from Alice Springs, in liaison with the WRE patrol officers, was taken up the following year. In June, with an Aboriginal driver and guides from Papunya, I made a preliminary journey to Jupiter Well and met a group of 16 people in the Dover Hills. Returning next month we again met this group, then numbering 28 people, and made journeys off the road to the

93 Welfare Branch Annual Report 196768:128.
94 Ibid:130. 
south-west with Mr W.R. MacDougall, WRE patrol officer, where we met only nine people but were told of some 34 people living in the area. One family was taken to Papunya to allow the small son's burns to be treated but the rest were told that MacDougall would regularly visit to keep in contact. ${ }^{95}$ But as we left one group was already moving east, apparently heading towards Papunya. (Three men walked all the way but they were returned to their families by Macdougall in September when he again visited Jupiter Well and met two men of the group living in that area.) The Report noted the possibility that all these people might soon move in and drew attention to the problems these small groups faced, living isolated from their relatives who had already moved out to places like Balgo Hills and Haasts Bluff/Papunya.

After this patrol I suggested that the needs of some 50 Pintupi families at Papunya might best be met by helping them to establish camps within about $90 \mathrm{~km}$ of Papunya; that several bores might be sunk along the road to the border to make travel to and from Papunya safer; and that a small outpost should be established in the Ehrenberg Ranges and another later at the Western Australian border 'to provide central points for decentralised activity' in the Pintupi country. 96

MacDougall made another visit as far as Jupiter Well in mid-November 1962 and met a group of 25 camped near the border. Returning from the Petermanns at the end of April 1963, I drove north with Mr Brian Mitchell, patrol officer, and met MacDougall at the Kintore Range. We visited Dover Hills but found the waterholes dry and the only smoke we saw was far to the north towards Lake Mackay. Some rain fell in May and Pintupi at Papunya said they expected the people we had seen in Dovers Hills the year before to walk in within the next few weeks. By July four families - 16 people in all - had reached Papunya on foot.

At the end of July another patrol set out, this time with a journalist and an ABC cameraman to record and report on the journey. East of the Kintore Range we met a family of five who were walking in to Papunya and they were driven there by a vehicle which had carried extra fuel as far as Sandy Blight Junction. In the course of two trips as far as Jupiter Well, we met another 34 people, 15 of whom had been seen in 1962, and heard of some 40 to 45 others, a few of whom had met MacDougall on his September 1962 trip. It seemed evident that most, if not all, of these people intended to move in to Papunya. It was apparent that 'there [were] not enough people left for the social system to function effectively: young men cannot be initiated and young women cannot find appropriate husbands'. 97 We noted that two of the 34 people seen the year before had died and 'all children over 18 months or two years [were] more or less severely under-nourished and four out of 10 children under 10 years of age seen in the western groups had yaws'.98 In response to requests for transport in to Papunya we suggested that a truck might be sent out after the summer if all the authorities approved. But 'some made it fairly clear that they would walk in before then' and we left water along the road at Sandy Blight and the Ehrenbergs. 99

At the same time that we discussed the possibility of meeting their requests for transport to move them east we talked about the provision of waters for their use 'near the

\footnotetext{
95 Long: $1951 \mathrm{v}$.

96 Long 1962c.

97 Long 1963:9.

98 Ibid.

99 Ibid.
} 
Ehrenberg Ranges and ultimately further West'. ${ }^{100}$ In reporting on the patrol we again urged the early provision of bores near the Ehrenberg Ranges where recent immigrants and those still in the desert could live. If there was any delay in providing water there it was proposed that the desert people wanting to move in might be settled on natural waters near Mt Liebig where there were abundant kangaroos and where rations and medical services could be conveniently provided from Papunya. 101

In September/October of the same year, Dr Donald Thomson made a second desert expedition, six years after his visit to the Lake Mackay area. Travelling first to the Giles weather station, he headed north and met a group of people whom he refers to as Pitjantjatjara near Pankaberri rockhole in the Walter James Range. ${ }^{102}$ After filming and photographing the making of wooden artifacts, the party drove north to Sandy Blight Junction and west, finding recent tracks near Yumari rockhole and driving through the night until they came upon a camp of 'two women and three small boys' past Pollock Hills. 103 Next day they met a group of 'between twenty and thirty people' at a 'good deep well' in desert oak country (possibly Jupiter Well), and 'remained there for some time' before returning to Giles and to Melbourne. 104

The proposals made in my report were duly discussed with the Western Australian authorities and at the next meeting of the Central Reserves Committee in December plans were made for a joint patrol with Western Australian and WRE officers in April 1964. On that trip we met four separate groups - 42 people - all of whom were living as close to the road as the dry conditions allowed and all of whom seemed to have resolved to move in to join their relations at Papunya. At least some of those whom we had met previously but did not see this time had expressed strong interest in moving east. But it is likely that some men were deliberately keeping away from the road at this time because they did not want to move. In two separate trips these 42 people were taken in to Mt Liebig. We had left two men there when the patrol set out, to look at the natural waters in the area where the immigrants might camp. They reported that they had found no adequate supply. After looking at the main spring and discussing the situation, we decided to take the whole group in to Papunya. The report recorded that:

It was a stunning experience for the group to go in to this crowded settlement and the transition from nomadic to settlement living will be altogether too abrupt. It should, however, be possible for the health, at least, of the group to be kept under close watch there.

On the way out we had travelled with a geologist who chose sites for investigational drilling in the Ehrenberg Ranges. At the May meeting of the Central Reserves Committee the Northern Territory Director of Welfare (Mr H.C. Giese) outlined plans for 'a chain of bores west of Papunya (which) will assist the newcomers to move back and forth from their "countries" as they wish' (Minutes, Sixth Meeting of the Standing Committee on the Central Aboriginal Reserves held at Canberra on 4 May 1964). Our report noted that 67 people had by then walked or been brought to Papunya since August 1962 and these, 'with the 40-odd who immigrated between 1956 and 1958 and some immigrants from the Rawlinson Range area', make up a substantial proportion of the Papunya population. We

101 Ibid:10.

102 Thomson 1975:139-147.

103 Ibid: 153.

104 Ibid: 154. 


\section{LEAVING THE DESERT}

stressed the urgency of establishing a depot to the west where all these people could 'make their adjustment to a new way of life under more favourable circumstances:. 105

Later, in September 1964, MacDougall met a group of 11 near Jupiter Well who asked to be taken to join their close relatives who had gone in five months earlier. Two years later in July 1966 a group of 17 people from the southem sand ridge area west of Lake Macdonald came out to the road and were taken to Papunya by another WRE patrol officer (Bob Verburgt). These groups brought the number of immigrants in the ten years since 1956 to about 160 . It was known that a group of at least seven people remained out in the country west of Lake Mackay but the adult male in the group had lived at Balgo Hills Mission for some years and could therefore take this group there when and if he wanted to.

The need for an outpost to the west of Papunya where these people could live was urgent but thirteen investigational bores sunk near Ilpili found no adequate supplies. For the next ten years and more they lived either at Papunya or at various bores 30 to 70 kilometres to the west of Papunya. The failure to find water at the Ehrenberg Range was discouraging, and in the late 1960s and early 1970s, efforts to provide water for the use of the 'new Pintupi' were focussed on areas closer to Papunya. But several of the new arrivals found it impossible to adjust to the strange life at Papunya. Within weeks of the group's arrival in April 1964 there were reports of acute malnutrition particularly among the women and eleven of the group were being given special medical treatment for malnutrition. Most of these were evacuated to Alice Springs Hospital and several recovered, at least temporarily, but by August 1964 six had died, despite the strenuous efforts made by the nursing sisters and others to encourage them to eat. The District Welfare Officer, who visited to report on the situation early in July, noted that the new arrivals 'appear to be despised by the majority of Papunya people who openly laugh at them and 'rubbish' them rather than making any attempt to help them'. ${ }^{106}$ He proposed encouraging them to camp at waters far enough from Papunya to allow them to live a life more like the one to which they were accustomed. The groups that came later in 1964 or in July 1966 did not fare so badly, but in all by September 1966, 15 of the 116 people who had walked or been brought to Papunya since 1962 had died: nine adult women, five adult males (three of them in their sixties) and just one male child ${ }^{107}$ Hopes that providing transport for these people would mean that they suffered fewer health problems than the group which had walked in eight years earlier were, as it turned out, unjustified. In retrospect it seemed that the acute health problems might have been avoided if the original plan to establish the new immigrants with a few of their relatives in camps well to the west of Papunya had been followed. In the five years 1962 to 1966 there were altogether 129 deaths in the Papunya population of about 800 . (There were also 204 live births.) These were the last and worst years of the ten-year drought that afflicted Central Australia: good rains fell in the summer of 1966/67. The new arrivals were exposed to diseases to which they had little resistance and conditions at Papunya favoured the spread of infection. Life there in the 1960 s was significantly more institutional than life at Haasts Bluff in the 1950 s, notably because a system of communal feeding had been established at all the government settlements in the Territory in this period - a system with which the immigrants found particularly difficult to cope. The replacement of the Haasts Bluff ration store with the Papunya kitchen and dining room meant that it was

Ibid:4.

106 Memorandum District Welfare Officer to Assistant Director (Southem), 13 July 1964, Welfare Branch File 63/443. 
no longer such a simple matter to supply food to groups who wanted to live elsewhere on the reserve.

The reluctance of local officials to provide services to groups living away from Papunya became less strong in the late 1960s and large groups of Pintupi were from time to time established at western bores like Waruwiya ( $56 \mathrm{kms}$ ) in 1968/9 and Alumbara (32 $\mathrm{kms}$ ) in 1970. In September 1971 officials began more ambitious planning for a satellite community for the Pintupi, selecting a site to the south-west where there were prospects of finding good water. ${ }^{108}$ After the December 1972 change of government, officials in Canberra and in the Territory were keen to give support to 'outstations' as they were called. A new pastoral bore attracted the interest of the Pintupi at Papunya and in June 1973 a large camp of some 200 Pintupi was established at Yayayi bore (40 kms west of Papunya). Apparently in an effort to persuade the authorities to maintain grants for the Yayayi venture, the people stressed that they wanted to stay there permanently and had no interest in moving farther west.$^{109}$ In 1974 another outstation was established at Kungkayunti (112 kms by road south-west of Papunya) and later groups were camped at Yinyilingki and New Bore, north of Mt Liebig. At the same time several outstations within $20 \mathrm{kms}$ of the settlement were occupied by other groups from Papunya. The 1970s thus reproduced a pattern rather like that of the 1950s when many of the people based at Haasts Bluff had lived for much of each year at camps on natural waters or at bores along the ranges to the west. In the 1970 s the outstation groups had access to wages and Social Security payments and bought food and other goods. As incomes and government grants increased they acquired cars and trucks and began to make independent journeys to visit, and be visited by, relatives at Yuendumu, Balgo Hills to the north and Docker River, Warburton and other communities to the south and west.

Meanwhile Pintupi men had been able to revisit their country, most notably on a series of journeys with the film unit of the Australian Institute of Aboriginal Studies in 1969, 1970 and 1972. For these visits buses were hired and parties of 30 and more men were taken west to re-enact rituals at important sites. On these and other occasions when researchers took vehicles out to the west, Pintupi men took the opportunity to gather large numbers of spear shafts in the sand ridge country west of Pollock Hills.

For the Pintupi the next big change came when satisfactory water was at last found by boring near Ilpili where an outstation was established for a time in 1979 and then in four bores sunk at and near the Kintore Range in 1979/80. In mid-1981 an outstation was established at the Kintore Range, and this place was developed as a 'resource centre' for camps elsewhere in the region. Bores were later equipped with hand pumps farther west at Ininti, Muyingu, Mantati, Yumari and Winparrku (Mt Webb) and in 1983 Kiwirrkurra, near Pollock Hills, some $460 \mathrm{kms}$ west of Papunya, was developed as another 'resource centre'. The provision of bores and services in these places allowed the reoccupation of at least some of the Pintupi country.

Ironically this reoccupation of their traditional lands brought to light the fact that one group had remained behind in the desert when all their relatives left. In October/November 1984 two young men appeared and spoke to a man and his son who were camping at the Mt Webb bore, but then fled. A party set out in vehicles from Kiwirrkurra, followed the two

108 NT Welfare Division Annual Report 1971-72:65-9.

109 Coombs 1974:138. 


\section{LEAVING THE DESERT}

back to their camp and persuaded a group of nine to accompany them back to Kiwirrkurra. 110

\section{'Like perishing bullocks'}

For many years one of the widespread beliefs about the history of Aboriginal disposession in Australia was that groups had been driven from the productive and well watered areas and had taken refuge in the arid interior. This kind of white Australian folklore, which can be traced back to Governor Macquarie's day, seems in recent decades to have disappeared from the literature, though it may well linger in the popular imagination. The converse proposition, that Aboriginal people abandoned their hunting ranges to exploit the new resources of food and water and tobacco and other goods available at station homesteads, mining camps, mission stations, ration depots and townships, has, it seems, over time earned a measure of popular acceptance. One view of Aboriginal people as helpless victims, pushed into the 'harsh interior' by greedy settlers has been replaced by another view which sees them forced by the offer of easily available food and other goods into dependency, victims of a less obvious form of coercion. ${ }^{111}$

In this account of what seems to have happened in one part of the 'Western Desert frontier' a little direct evidence has emerged of the kind of hopes and fears that may have directed Aboriginal choices, though the emphasis has been on how the actions of travellers and prospectors, missions and governments may have influenced those choices. It seems possible to draw some inferences from the exceptional cases, the instances where individuals evidently decided not to move in and engage in what Rowse has termed 'an experiment in a different way of living: ${ }^{112}$ Some of these seem to have tried the experiment and decided they did not like it. Some had good reasons for avoiding their fellows, fearing violent retribution, and as the desert population shrank the likelihood increased that marriages would be contracted between closer kin than custom approved.. ${ }^{113}$ There is no evidence of overt white violence on the 'Pintupi frontier' and one might assume that fear of such violence would not have been an important deterrent to those contemplating the walk in, though limited and uncertain knowledge of the intervening country and fear of the unknown may well have dissuaded some groups from moving. But there were some violent episodes in the southern areas: Giles' party, for example, used pistols and rifles to beat off spear attacks in the Petermann and Rawlinson ranges in 1873. The men met at Yarangga in November 1957 confessed that they thought we were going to kill them and had a story that

110 Reporting on 2 March 1961 on information gathered at Yuendumu about people then still 'out bush', I listed a man of the 'Jungarai' subsection; on the 1962 patrol I heard more of this man who was said to have three wives and two of whose children were said to be at Yuendumu; it appeared that there were no more than 10 people remaining in his group. In a note of May 1963 after a visit to Papunya and Yuendumu, I mentioned that this man was then thought to be dead. This was confirmed by people we met in April 1964 who reported that a man of the Tjapanangka sub-section who had retumed to the desert from Balgo Mission was living with one or all three of the widows. On a visit to Balgo Mission in May 1967 I gathered more information on this man who was said to have left his wife and three children and walked into the desert in about January 1961. It was clear then that he chose to remain in the desert and members of his group only sought contact in 1984 after he had died. See also Peterson 1986:105.

111 See Rowse 1986.

112 Ibid: 198

113 See, e.g. Peasley 1983, Chapter 2. 
some people had been shot and killed near a settlement to the south in an incident involving camp dogs stealing food. There had certainly been earlier incidents involving police and others in Central Australia to provide some basis for rumours of apparently irrational use of firearms circulating beyond the frontier. The fact that migrations from desert homelands sometimes appeared to be a direct response to the urgings of relatives revisiting those homelands (as in the instance of the 1956 migration) or followed friendly visits by relatives accompanying prospecting, government or mission parties may suggest that fears inhibited emigration. It can be assumed that in any group some welcomed the prospect of change and of new experience and readily adapted to the new circumstances, while others put a higher value on the life they knew, hazardous and uncertain as it might be.

The emigration from the Western Desert was a lengthy process, extended over more than sixty years and the conditions in which the first and the last emigrants left their homelands were very different. Curiosity may well have been the main motive for the first Pintupi undertaking the walk in to Hermannsburg. To maintain contact for ritual and social purposes with their disappearing eastem neighbours, Pintupi would have found it necessary to move east. It seems that some parties came in during dry spells and the intense and protracted drought of the early 1960 s probably encouraged interest in moving out but there is little real evidence for a direct causal link between emigration and the weather: the widespread movement from the Westem Desert in the mid-1950s occurred before drought conditions set in. It does not appear that a craving for tobacco was the powerful motivator that it was farther north in Arnhem Land and elsewhere and the ready availability of wild tobacco (minggulpa) in the desert may account for this. Pastor Albrecht, writing in 1941 as a concerned observer of the early years of emigration from the desert, remarked that, for Aboriginal people who had had some contact, 'the time ... soon comes when life under bush conditions is regarded worse than prison, and unless something is done to make it more attractive, they will go and leave for the settled area'.114 For the small number remaining in the desert in the $1960 \mathrm{~s}$ and later, their increasing isolation and narrowing range of human contact must indeed have made life 'in the bush' seem dull and any prospect of change seem exciting and attractive.

A certain amount of white Australian folklore about government policy and practice has accumulated over the intervening years. A belief that governments in the 1950 s and 1960 s tried to clear the desert for purposes associated with weapons testing at the Woomera Rocket Range has, it seems, widespread currency. The remoteness of the Petermann Range and Pintupi country from the Maralinga and Emu atomic testing grounds makes it implausible that the test programs could be shown to have had any effect at all on those areas or their inhabitants. Serious suggestions have, however, been made that transport to Papunya was offered to Pintupi people in 1964 and 1966 because there was an 'official policy of centralization', apparently for purposes of 'assimilation', but also that 'the Pintupi were not being protected from starvation, but rather, from the WRR (Woomera Rocket Range) .115 The implication is that the Pintupi were removed from the rocket testing range to get them out of harm's way and some Aboriginal informants have recalled officers warning people of rockets. As Rowse has pointed out, however, no evidence is cited of any official concem about 'falling projectiles'. ${ }^{116}$ The WRE patrol officers were appointed to help ensure that the activities associated with the Woomera Rocket Range caused

\footnotetext{
114 AA/F(26.30: letter of 15 August 1941.

115 Nathan 1983:68.

116 Rowse 1986:194-5.
} 


\section{LEAVING THE DESERT}

minimal interference with the lives of Aboriginal people living in the Western Desert and in the settled areas. They were given statutory appointments under the State and Territory legislation, they sent copies of their reports to the State and Territory authorities and they were expected to conform to the policies of those authorities. The Western Australian Department of Native Welfare wanted no disturbance of people in the desert and the patrol officers followed a policy of refusing to give lifts except when called on to carry people to or from hospital. They were also required to discourage groups in the Rawlinson Range from foraging in the garbage bins of the Giles weather station, where employees were instructed not to supply Aboriginal people with any food, in order to avoid disturbing their way of life. But this discouragement hardly justifies Rowse's view that Aboriginal people eventually taken to Papunya from there 'could be said to have been coerced in that they were not allowed near Giles even though it stood near good water'. Aboriginal groups regularly used, and were actually encouraged to use Sladen Waters (Warupuyu) and other natural waters near Giles, but were discouraged from attaching themselves to the weather station.

The 'no lifts' rule was relaxed only in 1964 after I had suggested that transport to Papunya be provided in response to Pintupi requests and this proposal had been accepted by the Western Australian authorities. MacDougall himself was unenthusiastic about the change of approach and had looked forward to continuing contact with the groups along the road between the border and Jupiter Well. The stories suggesting that people were warned to get out of the way of rockets are implausible because these inhabited areas were not under the flight path. (A group found living far to the north-west near the Percival Lakes, in the actual 'impact area' for firings of Blue Streak rocket was, I understand, offered transport to Jigalong by the Western Australian authorities. This group consisted of 20 women and children and the offer was not made because they were at risk from rockets. Apparently their male relatives had left the group some years earlier and had never returned.). ${ }^{117}$ If the 'coercion thesis' is to be given any credit at all, at least the WRE patrol officers should be absolved of responsibility.

There is, however, another sense in which the Woomera program and the WRE share some responsibility for accelerating the movement out of this and other parts of the western Desert. The grading of tracks through the desert made it a great deal easier for welfare authorities and others to visit the areas and, though they were cut mainly for the relatively innocent purpose of allowing map makers easier access, they almost immediately exposed the inhabitants to new contacts and to new choices. If the offers of transport to Papunya had not been made it is likely that most of the people would have walked there within two or three years. The breaking of the drought in the summer of 1966/67 would have made the journey less risky, though conceivably it might have encouraged some to stay and enjoy the relatively easy living of the next twenty years of good seasons. But it is certain that in the 1970s, when Pintupi and others at Papunya and at other communities acquired increasing numbers of motor vehicles, some of them would have used the tracks, washed out and overgrown as they became, to visit any of their relatives who might have remained and who lived close enough to the roads.

It has been these roads, occasionally improved by oil-search companies exploring in the area in the late 1960s and 1970s, which have made it feasible for governments in the $1980 \mathrm{~s}$ to provide the water bores and other services which have allowed the Pintupi to reoccupy the country from the Ehrenberg Ranges to the Pollock Hills. And what these people want in the 1980 s is more roads to give access to their homelands both north and south of the 1960 WRE road. 
The alternative, or supplementary, proposition that Pintupi people were coerced, prevailed upon or at least persuaded to move to Papunya in pursuit of an 'official policy of centralization' executed jointly by WRE and Northern Territory officers, is also implausible. ${ }^{118}$ The officers involved were consistently recommending 'decentralisation' and the provision of waters at a distance from Papunya in the way that was eventually achieved over the subsequent twenty years. No one could have supposed that the addition of another 40 or 70 people to the Papunya population was an important step towards a goal of 'assimilation'. Those officers who were making contact with the Pintupi were all, like their critics, imbued with the notion that Aboriginal people were better off living independently in the bush than choosing a sort of dependency in settlements. The managers and school teachers at the settlement may indeed have found it more convenient to provide services there than to try to devise ways of taking them to groups scattered farther west but this manifestation of 'assimilation' policy in practice affected the Pintupi only after their migration.

It has also been asserted that Pintupi people at Papunya, keen to return to the desert after 1964, were prevented or prohibited from doing so. There was never any obstacle that was or could have been placed in the way of people who might have chosen to walk back as so many had walked in and after the summer of $1966 / 67$ there was almost always plenty of water about. The commitment of the Northern Territory officials to the policy of providing waters to the west to allow people to return is perhaps enough to indicate that no instructions would have been issued to discourage or forbid the return of Pintupi families to their homelands. If, as claimed in John Greenway's reminiscences of his travels in the Centre, one of the WRE patrol officers thought he was not permitted to take people back, this policy was probably his own invention, perhaps based on conversations with local officials at Papunya. ${ }^{119}$ All the evidence suggests that the consensus view among the Pintupi emigrants was that a return to the desert was practicable only if and when services were provided there.

The 'coercion thesis' represents not simply a distortion or misreading of the evidence in the historical record. As Rowse has argued, it allows no room for Aboriginal initiative, apparently to avoid conceding that any Aboriginal people would ever voluntarily leave their homeland. ${ }^{120}$ This is unfair to the Pintupi. Over a period of some forty years most had made the decision to leave their desert homelands and most had walked out to Hermannsburg, to Haasts Bluff, to Warburton and to Balgo Hills. A few were able to induce the welfare authorities to abandon a firmly held policy of not assisting this emigration and instead to provide transport. This decision to accede to Aboriginal wishes was soon seen as an error, but it was a mistake of a kind rare at that time, when policies and practice were more often criticised for an excess of paternalism rather than for falling in with Aboriginal wishes.

The decisions to leave traditional country which the Pintupi and their neighbours to the south in the Petermann Ranges took were consistent with a tradition of opportunist exploitation of resources when and where they appeared. It was not a helpless 'drift' but a series of highly motivated and purposeful moves: as one emigrant from the Petermanns has put it 'we were like perishing bullocks' rushing to a waterhole. If their migrations meant that they abandoned, for a time at least, the care and use of the land they knew best, they

118 Nathan 1983:83, 93.

119 Greenway 1973:282.

120 Rowse 1986:198. 


\section{LEAVING THE DESERT}

also allowed them to re-establish links with their relatives and to establish new ties to many more people and this maintenance and extension of personal and ritual links was also a strong tradition. The pull of the homelands remained strong and for some of the emigrants the hope of being able to arrange to return sustained them during decades of voluntary exile and motivates their continuing efforts to win government support for the further development of services in those homelands.

\section{BIBLIOGRAPHY}

Albrecht, F.W. 'On Lasseter's Trail' Lutheran almanac 1964.

' On God's tracks in Central Australia' Lutheran almanac 1966:42-54.

'Going West' TS 1935 (Elkin Papers 1/12/147, University of Sydney Archives).

Anon., [Judy Inglis]. 'The outback Aborigines', Current affairs bulletin 23 (3) December 1958.

Bleakley, J.W. The Aborigines and half castes of Central Australia and North Australia. Report by J.W. Bleakley, Chief Protector of Aboriginals, Queensland, 1928. Melbourne, 1929.

Carnegie, D.W. Spinifex and sand. London 1898.

Coombs, H.C. 'Decentralization trends among Aboriginal communities' Search 5.4 April 1974.

Duguid, Charles. No dying race. Adelaide 1963.

Evans, E.C. Report on patrol to Lake Mackay area JunelJuly 1957. Report on patrol Lake Mackay - Kintore Range areas, July 1960.

Evans, E.C. \& J.P. Long. 'The Aborigines of western central Australia'. Geogrl J. 1965. 131:318-29.

Fry, H.K. 'Kinship in western central Australia' Oceania IV.4. 1934:472-478

Giles, Emest. Australia twice traversed. London 1889.

Greenway, John. Down among the wild men : the narrative journal of fifteen years pursuing the old stone age Aborigines of Australia's western desert. Melbourne 1973.

Hargrave, John. 'Medical survey' (Lake Mackay) 1957 (AA:CRS FI.55/320).

Hartwig, Mervyn. 'The progress of white settlement in the Alice Springs district and its effects upon the Aboriginal inhabitants 1860-1894'. Ph.D. thesis, University of Adelaide, 1965.

Hercus, Luise. 'Leaving the Simpson Desert' Aboriginal History 9(1) 1985:22-43.

Kimber, R.G. 'The Pintupi of the Kintore Ranges 1982: Historical survey' unpublished report for the Department of Aboriginal Affairs, Alice Springs, Feburary 1982.

'Papunya - the dialogue of the country' in N. Amadio \& R. Kimber. Wildbird dreaming. Melbourne, 1988.

Kolig, Erich. The Noonkanbah story. Dunedin, 1987.

Leske, E. (ed.). Hermannsburg: a vision and a mission. Adelaide, 1977.

Long, J.P.M. 'Daily journal of patrol to the Kintore Range area: October/November 1957 and Report on the present numbers and condition of the nomadic Pintupi'. Ts. 1957

'Visit to central reserve area with Patrol Officer Macaulay'. Ts 1961a.

'Preliminary report on the movements and rate of growth of the population of Areyonga'. Ts $1961 \mathrm{~b}$.

'Visit to the Petermann Ranges, September 1961: general report and recommendations and daily journal'. Ts $1961 \mathrm{c}$.

'Report on preliminary patrol west of Papunya (June 11-17)'. Ts 1962a.

'General report on field trips west of Papunya (June 23-July 21)'. Ts $1962 \mathrm{~b}$.

'Proposals relating to the future of the Pintupi at Papunya. 25 July 1962c'. Ts.

'Fieldwork west of Papunya June - July 1962. 10 August 1962d'. Ts. 
'Visit to the Petermann Ranges, April 22 to 29, 1963'. 2 May 1963. Ts. 'Report on Patrols west of Papunya, August 1963. 12 Sept 1963'. Ts.

'Report on Patrol west of Papunya, April 1964'. Roneo Darwin, 1964.

'The Pintubi patrols: welfare work with desert Aborigines' Australian Territories $4(5): 43-8,4(6): 24-35,1964$.

Mackay, Donald. 'The Mackay aerial survey expedition, Central Australia, May - June 1930'. Geogrl J 84-6, 1934:511-514.

Meggitt, M.J. Desert people: a study of the Walbiri Aborigines of central Australia. Sydney, 1962.

Mulvaney, D.J. and J.H. Calaby. So much that is new: Baldwin Spencer 1860-1929. Melbourne, 1985

Myers, Fred R. Pintupi country, Pintupi self: sentiment, place and politics among western desert Aborigines. Canberra, 1986.

Nathan, P. \& D. Lechleitner Japanangka. Settle down country. Malmsbury, 1983.

Northem Territory (NTA). Report of the Administrator for the year ended 30 June 1922. Melbourne, 1923

Report of the Administrator of the Northern Territory for the year ended 30 June 1924. Melbourne, 1925.

Report of the Administrator for the year ended 30 June 1925. Melbourne, 1926.

Report on the Administration of the Northern Territory for the year ended 30 June 1937, Canberra, 1938.

Report on the Administration of the Northern Territory for year 11939-40, Canberra, 1941.

Report on the Administration of the Northern Territory for year 1945-46, Canberra, 1947.

Peasley, W.K. The Last of the nomads. Perth, 1983.

Penny, D.H. with K. Davis and J. Hunter. 'Papunya: history and future prospects'. Unpublished report for the Ministers for Aboriginal Affairs and Education. Canberra, 1977.

Peterson, N. with J. Long. 'Australian Territorial Organisation' Oceania Monographs 30. Sydney, 1986.

Read, Peter \& Engineer Jack Japaljarri. "The price of tobacco: the journey of the Warlmala to Wave Hill, 1928'. Aboriginal History 2, 1978:141- 148.

Roheim, Geza. Children of the desert: the western tribes of central Australia. New York, 1974 [1974a].

The riddle of the sphinx. New York, 1974 [1974b].

Rowley, C.D. The destruction of Aboriginal society. Canberra, 1970.

Rowse, Tim. 'Aborigines as historical actors: evidence and inference'. Historical Studies 22.87. 1986:176-198.

Spencer, W.B. Through Larapinta land: a narrative of the Horn Expedition. Melbourne, 1896.

'Preliminary report on the Aboriginals of the Northern Territory' Northern Territory' Bulletin No. 7, Melboume 1913.

Stanner, W.E.H. 'Durmugam, a Nangiomeri' in J.B. Casagrande (ed.) In the company of man." twenty portraits of anthropological informants. New York, 1960.

Strehlow, T.G.H. 'Report on trip to Petermann Ranges, July-August 1939'. Ts 1939.

Terry, Michael. Sand and sun: two gold-hunting expeditions with camels in the dry lands of central Australia. London, 1937.

'Explorations near the border of Western Australia'. Geogrl J. 84.6. 1934:498-510.

Thomson, Donald. Bindibu country. Melbourne, 1975.

Tietkens, W.H. Journal of Mr W.H. Tietkens' central Australian exploring expedition. S.A. Parliamentary Papers 4.111. .

Tindale, Norman B. Aboriginal tribes of Australia: their terrain, environmental controls, distribution, limits and proper names. Canberra 1974. 
Tonkinson, R. The Jigalong mob: Aboriginal victors of the desert crusade. Menlo Park, 1974.

The Mardudjara Aborigines: living in the dream in Australia's desert. New York, 1978.

Walker, C.H. Diary Walker bros prospecting expedition. MSS 1913 (AA:crs A1/1, 34/9205).

Warburton, P.E. Journey across the western interior of Australia. London, 1875.

Winnecke, Charles. Journal of the Horn scientific exploring expedition 1894. Adelaide, 1897.

Identification of files in Australian Archives.

Australian Archives (AA:CRS) Northern Territory branch

F1, 38/418

F126, 30

F1, $52 / 440$

F1, 55/382

F1, 55320

F3, 32/3
Aboriginal reserve southwest corner of the Territory

Haasts Bluff

Haasts Bluff native settlement daily journal

Welfare Branch: Haasts Bluff reserve monthly reports

Welfare Branch: Tribalised Aborigines west of Mount Doreen

P.O. Strehlow monthly reports. 